REVISTA DE DERECHO UNED, núm. 4, 2009

\title{
MATRIMONIO Y DERECHO EN «EL CURIOSO IMPERTINENTE». LO QUE VA DE CERVANTES A GUILLÉN DE CASTRO
}

\author{
ENRIQUE VIVÓ DE UNDABARRENA \\ Profesor Honorario de la UNED
}

Resumen: Guillén De Castro es en su siglo el dramaturgo más importante de la escuela valenciana. Parte de su dramática ofrece cuestiones de la vida conyugal tema insólito en el teatro español del XVII. "El Curioso impertinente», una de las cumbres de su producción aunque tome el argumento la Novela cervantina, Guillén al hacerlo Comedia lo transforma con sustanciales diferencias: Frente a la presentación de Cervantes de un matrimonio contraído posiblemente sin la necesaria discreción de juicio y con incapacidad para relaciones conyugales válidas, la creatividad de Guillén aporta además de otras cuestiones como la libertad de elección de pareja, el tema del adulterio y el crimen que impiden el matrimonio, pero en cuyos límites de configuración jurídica Guillén sabe detenerse, mostrándose buen conocedor de las sutilezas del Derecho Matrimonial Canónico.

Vocabulario: Tragicomedia. Impertinencia y curiosidad. Amor y Amistad. Convencionalismos del honor. Abuso del poder público y privado. Los «apartes», técnica dramática. Formas vicariantes. «Miles gloriosus» (soldado fanfarrón). «Corpus Iuris Canonici»: el Decreto y las Decretales. Adulterio con promesa de matrimonio. Homicidio y conyugicidio.

Sumario: INTRODUCCIÓN: Anotaciones biográficas. Precedentes e influencias. El Título: La impertinencia y la curiosidad patológica. La Comedia respecto a la Novela. Contenido, estructura y ritmo. La temática del amor conyugal y la amistad 
LA COMEDIA EN TRES ACTOS: Dramatis peronae: Los protagonistas y los personajes secundarios. El Primer acto y el porqué de su invención: Se acuerda casar a Camila; Lotario cede la novia a Anselmo enamorado y pide su mano para su amigo.El Acto segundo: La propuesta impertinente de Anselmo y su inicio. Asechanzas cortesanas que estimulan. Prueba de celos y rendimiento de Camila. Acto tercero y desenlace: La denuncia del celoso despechado. Venganza de Leonela que descubre la farsa. Final con desafío, muerte y bodas.

CONSIDERACION MATRIMONIAL Y JURIDICA:Los conflictos matrimoniales en Guillén. Casarse con quien se adulteró. El conyugicidio y adulterio. El impedimento de crimen en el Corpus Iuris Canonici. CONCLUSIONES

\section{INTRODUCCION Y GENERALIDADES}

\section{I.1. Anotaciones biograficas}

Guillén de Castro y Bellvís nace en Valencia el 4 de noviembre de 1569 de nobles valencianos ${ }^{1}$. Tras un fallido desposorio en 1593, contrajo nupcias el 17 de diciembre de 15952; enviudando, celebró nuevo matrimonio en $1625^{3}$, en el que la dote de la esposa le permitió pasar con desahogo el resto de sus días ${ }^{4}$. Murió en Madrid el 28 de julio de 1631.

${ }^{1}$ LOPE DE VEGA, Las almenas de Toro (1620): Le llama "caballero valenciano», y con razón, pues este título otorgado por Carlos I lo había heredado de su abuelo. A los 21 años Guillén debió de conocer a Lope de Vega, que influyó en él con su concepción nueva del teatro. En 1621 dedicaba la segunda edición de sus Comedias a Marcela de Vega Carpio, la hija de Lope.

2 J. OLEZA, Introducción a edición de "El Curioso impertinente», Madrid 1997, p. 4s.: La desgracia familiar le acompaña, pues en 1597 moría su madre y poco después su esposa y su única hija, lo que dejó numerosos testimonios de infelicidad conyugal en sus obras.

${ }^{3}$ FALIU-LOBATO, Introducción a su edición de "El Curioso impertinente», Reichenberger, 1991, p. 5: Casa con una dama de compañía de la esposa de su protector el duque de Osuna, treinta años más joven que él, extraña unión para quien había satirizado en sus comedias el casamiento de varones provectos con jovencitas.

${ }^{4}$ J. OLEZA, loc. cit. p. 9: En todo caso debieron ser para Guillén de Castro estos últimos años bastante mejores que hasta entonces acosado por las deudas. 


\section{I.1.A. Ámbito literario}

Valencia de rica tradición teatral era foco de creación dramática con estilo propio 5 .

Guillén a los 25 años, segundón sin un patrimonio, buscó protección a cambio de servicios entre la alta nobleza, pasando pronto a Italia de donde regresa hacia 1609.

A comienzos del 1619 marcha a Madrid sirviendo al duque de Osuna, tiempo en que intensificó su actividad literaria ${ }^{6}$. Con pleno reconocimiento como poeta dramático, es elogiado de los dramaturgos contemporáneos ${ }^{7}$.

\section{I.1.B. Discípulo anómalo de Lope de Vega}

Se considera a Guillén el dramaturgo más importante de la escuela valenciana de fines del siglo XVI. Es calificado de discípulo anómalo del Fénix ${ }^{8}$ : por su distinto concepto del honor y de las convenciones de la honra; por su planteamiento de los problemas matrimoniales poco habitual en el teatro de entonces; por la importancia que da al dinero en el que la escuela de Lope iguala idealmente a la sociedad, y por su visión del poder criticando sus abusos ${ }^{9}$.

${ }^{5}$ Cfr. TERESA FERRER VALLS, Teatro Clásico en Valencia, vol. I, Madrid 1997: Hay una generación de trágicos con Rey de Artieda y de comedia con el canónigo Tárrega el maestro de Guillén de Castro.

${ }^{6}$ J. OLEZA, loc. cit. p. 7: Allí participa en numerosos certámenes literarios como los convocados aquel año por la beatificación de san Isidro Labrador, en que el Fénix, en calidad de secretario de aquellas justas poéticas dedica versos laudatorios a Guillén de Castro concursante ganador.

${ }^{7}$ LOPE DE VEGA, El laurel de Apolo, Madrid, BAE, 1872, tomo XXXVIII, p. 195. CERVANTES, Viaje del Parnaso. Madrid, Castalia, 1980, p. 86. AGUSTÍN DE ROJAS, El viaje entretenido, Madrid, Castalia, 1972. p. 156. JUAN PÉREZ DE MONTALBÁN, Canto IV de Orfeo en lengua castellana, Madrid, CSIC, 1948, p. 102. BALTASAR GRACIÁN, Arte de ingenio. Tratado de la agudeza Madrid, Castalia, 1969, vol. II, p. 138.

${ }^{8}$ GEMMA DOMINGO CARVAJAL, Tipología de los personajes en la dramaturgia de Guillén de Castro Tesis. Barcelona 2005, n. 4: Por su edad (tan sólo siete años más joven que Lope de Vega) y formación con autores de madurez artística en la Valencia de fines del Quinientos, lo que le aleja bastante del perfil tópico del discipulado de Lope de Vega.

${ }^{9}$ YOLANDA PALLÍN, Entrevista con la autora de la versión teatral, en "Cuadernos Pedagógicos 23», de la Compañía Nacional de Teatro Clásico, p. 33: El noble sin bienes de fortuna de su propia biografía lo reproduce en sus comedias. Así mismo el tema del poder del que precisamente en El curioso impertinente se hace un análisis complejo en las relaciones públicas y privadas. 


\section{I.2. Estima de sus coetáneos, olvido y reivindicación}

1. Sorprende su escasa estima en el «siglo de las luces», en el que la figura de Guillén pasó con más pena que gloria, pues solo se tuvo en cuenta su comedia Las mocedades del Cid como referencia de la de Corneille.

2. A mediados del siglo XIX, Mesonero Romanos se queja de tal olvido $^{10}$. Menéndez Pelayo en 1884, encabeza a sus primeros revindicadores que ponderan su originalidad respecto a la fórmula de la Comedia consagrada por Lope ${ }^{11}$.

3. A partir de estos autores han surgido los investigadores de la singularidad del valenciano en el concierto teatral del Seiscientos ${ }^{12}$; la crítica americana ${ }^{13}$ y aportaciones de la Universidad de Valencia ${ }^{14}$.

\section{LOS CONFLICTOS CONYUGALES EN GUILLÉN DE CASTRO}

\section{II.1. Tema insólito en el teatro español del XVII}

En la dramática de Guillén de Castro se ofrecen de forma original cuestiones de la vida conyugal, tema infrecuente en el teatro español del XVII que rehuyó mirar la vida cotidiana de los casados en el interior de sus hogares.

${ }^{10}$ MESONERO ROMANOS, Dramáticos contemporáneos a Lope de Vega, Biblioteca de Autores Españoles, Madrid, 1951, p. XXXIII: «Absoluto olvido en que por espacio de tanto tiempo se ha tenido el repertorio de este campeón de nuestro teatro, uno de los más esforzados caudillos de nuestra escena poética del siglo XVII».

${ }^{11}$ M. MENÉNDEZ PELAYO, Calderón y su teatro, Madrid, 1884, p. 82. HENRI MÉRIMÉE, El arte dramático en Valencia: Desde los orígenes hasta principios del siglo XVII, tomo II, Valencia 1913. EDUARDO JULIÁ MARTÍNEZ, Obras de Don Guillén de Castro y Bellvís, Madrid, 1925-27. Y Medio siglo más tarde J. M. ROCA FRANQUESA, Un dramaturgo de la Edad de Oro: Guillén de Castro, en Revista de Filología Española, XXVIII, 1944, p. 378ss.

${ }_{12}$ LUCIANO GARCÍA LORENZO, El teatro de Guillén de Castro, Barcelona, Planeta, 1976. CHRISTIANE FALIU-LACOURT, Un dramaturge espagnol du Siècle d Or: Guillén de Castro, Toulouse, Université de Toulouse-Le Mirail, 1989. I. ARELLANO, Del relato al teatro: la reescritura de El curioso impertinente cervantino por Guillen de Castro: En Criticón, 72, 1998, pp. 73-92. Artículo del que nos servimos por ser resumen de las aportaciones anteriores.

${ }^{13}$ JOHN G. WEIGER, La comedia nueva: una vez más sobre el juego de la originalidad, en Cuadernos de Teatro Clásico, 1, Madrid, Ministerio de Cultura, 1989, p. 14.

${ }^{14}$ JOAN OLEZA, loc. cit. y Josep Lluís Sirera, Teresa Ferrer, Juan Luis Ramos, vinculados al Departamento de Literatura española de la Facultad de Filología de la Universidad de Valencia. 


\section{II.1.A. Infortunios matrimoniales}

Al traer a escena los conflictos matrimoniales muestra la ingeniosidad de un dramaturgo calificado de poco convencional ${ }^{15}$.

Se reflejan tal vez en ello los infortunios matrimoniales de Guillén, cuyo primer desposorio fracasó, que perdió pronto a su segunda esposa e hija, y que luego con 56 años casó con mujer de 26, consiguiendo un mejor estar económico.

\section{II.1.B. El matrimonio cautiverio y yugo}

1. En El amor constante tal vez su obra más antigua, el protagonista se pregunta:

Sin amor ¿puedo querer?, y se responde: ;Ah matrimonio, cautiverio el más pesado! ${ }^{16}$.

En Fingir es cosa mortal, uno de sus personajes confiesa: Quien finge con su mujer con el mismo infierno lucha.

Y en El Conde Alarcos, la condesa exclama:

Maldigo a quien quisierel hombres, pues no puede ser/ confiarse una mujer/ del hombre que más le quiere.

2. Aun en comedia como La verdad averiguada y engañoso casamiento, en que resplandece un amor conyugal constante, se desliza esta pintoresca definición del matrimonio del gracioso:

Es un yugo a la garganta;/ y un dúo que canta mal,/ porque llora cuando canta./ $Y$ demás desto, a comer / siempre mujer y a cenar / siempre la misma mujer.

\section{II.2. Los mal casados de Valencia}

\section{II.2.A. ¿Autobiográfica?}

Es en esta comedia donde lo conyugal pudiera tener mayor sentido autobiográfico. Su tema central es el de las frustraciones y engaños entre las damas y caballeros en la comercial Valencia.

${ }^{15}$ JOAN OLEZA, loc. cit. p. 13

16 VALBUENA PRAT, Historia de la Literatura española, vol. II, Barcelona 1946, p. 87: La comedia desarrolla una retorcida escena de celos y hastío, en que un rey enamorado de una dama, finge y disimula ante la esposa, hasta que al fin prorrumpe en esta insólita declaración. 


\section{II.2.B. Don Álvaro «casado y arrepentido»}

Don Álvaro llega a su casa después de un viaje, acompañado de su amante vestida de paje. En el encuentro con Hipólita su cónyuge, el movido diálogo tiene sabor de cosa vivida.

— ¿Qué habéis hecho?

-He negociado

- ¿Todo, negocio ha sido?

- He paseado

- ¿Y servido a damas?

$-\mathrm{No}$

- ¿Ni hablado?

-Ni hablado

-Yo lo dudo

-Yo lo sé.

-Y déjame por los cielos; /que tan juntas me cansan tantas preguntas, / tanto enfado y tantos celos./Ahora llego...

${ }_{-}$YY te alborotas?

—Dejarades que me quitara /las espuelas y las botas...

¡Oh matrimonio/yugo pesado y violento;/si no fueras sacramento / dijera que eres demonio!

\section{EL CURIOSO IMPERTINENTE}

La mayoría de los lectores de El Quijote no han prestado particular atención a la Novela de El curioso impertinente salvo los filólogos y psicólogos. Apenas se ha estudiado esta Novela desde el punto de vista jurídico matrimonial. Lo mismo cabe decir de la Comedia de Guillén de Castro en la que entendemos que las cuestiones jurídicas aumentan y se sutilizan.

\section{III.1. De la novela a la comedia}

Guillén escribe esta Comedia en 1606, aproximadamente un año después de la edición del Primer Quijote, lo que parece mostrar que le 
causó una fuerte impresión la Novela insertada; adviértase que utiliza los mismos nombres de los personajes, y que además le proporciona material para su temática sobre el matrimonio y la amistad, sugeridos en la Novela cervantina ${ }^{17}$.

\section{III.1.A. Impertinencia y curiosidad patológica}

1. Es el mismo Cervantes quien nos plantea la cuestión de la «pertinencia» de la Novela intercalada.

Guillén parecería recoger el guante que el cura tiende, al expresar su perplejidad, concluida la lectura ${ }^{18}$. Pero la Novela tiene la función de aconsejar a las dos parejas que invadidas por encontrados sentimientos amorosos, se vuelven a juntar en la Venta, siendo iluminadas sus vidas con el ejemplo paradójico de El curioso impertinente ${ }^{19}$.

2. Los críticos generalmente se declaran por la pertinencia de la Novela $^{20}$, entendiendo que Anselmo como don Quijote confunde el mundo imaginado con la realidad ${ }^{21}$, siendo la curiosidad de Anselmo más bien propia de un enfermo mental ${ }^{22}$.

${ }^{17}$ JOAN OLEZA, loc. cit. p. 16: El Curioso impertinente, junto con Don Quijote de la Mancha y La fuerza de la sangre, es el tríptico de obras con que Guillén pagó tributo a Cervantes, llevando al teatro bajo el título Don Quijote de la Mancha los episodios de Cardenio y Dorotea, y en La fuerza de la sangre el tema del amor entre personas de condición social desigual.

${ }^{18}$ QUIJOTE II,3: Dice el bachiller Carrasco que «Una de las tachas que ponen a la tal historia es que el autor puso en ella una novela El curioso impertinente; no por mala, sino por no ser de aquel lugar». Y en I, 35: «No se puede imaginar que haya marido tan necio que quiera hacer tan costosa experiencia como Anselmo».

${ }^{19}$ ELENA PERCAS DE PONSETI, Cervantes y su concepto del arte (Madrid-1974), p. 214s.: La catarsis que experimentan da veracidad al de otro modo inverosímil desenlace feliz de sus vidas. Cervantes rescata a sus personajes inverosímiles ante el espectáculo de personajes psicológicamente auténticos.

${ }^{20}$ M. UNAMUNO, Cervantes y la comedia española en el siglo XVII. Salamanca, 1980, p. 66: La opinión de este autor original es más bien solitaria.

${ }^{21}$ HANS-JORG NEUSCHAFER, loc. cit. p. 106 : Pero mientras que en la acción principal la destrucción resulta relativamente inofensiva y tiene en general consecuencias más bien cómicas, que no ponen en peligro al mundo con el que entran en contacto, la novela intercalada trata de una destrucción verdadera y completa.

${ }^{22}$ GARCIASOL, Claves de España: Cervantes y el "Quijote», Madrid 1969 p. 236: Su mal deseo es una aberración obsesiva de la mente. Anselmo necesita certeza metafísica, un testimonio extendido por la divinidad asegurándole que su mujer es fiel y lo será. Pide certeza más allá de los límites de la razón. Pretende violentar los cimientos del mundo moral y perece en su demanda.

J. CASALDUERO, Sentido y forma del Quijote, Madrid 1973, p. 158: La figura cervantina de Anselmo hubiera podido ser únicamente cómica pero va derechamente a la tragedia. 
Sería lógico que la misma cuestión se suscitase en la comedia, sin embargo la curiosidad de Anselmo no parece inmotivada, dada la corrección de Guillén, que sugiere que Anselmo ha querido estar seguro de su esposa y de su amigo anteriormente enamorados.

\section{III.1.B. La comedia respecto a la novela}

1. La primera diferencia entre la Novela y la Comedia tiene que ver con ser géneros sustanciales diversos: En Guillén como dramaturgo prima la acción. La comedia destila visceralidad proliferando en escena asuntos como los celos, el abuso de poder, la manipulación, los convencionalismos del honor, y de manera más sutil, la sensualidad y el erotismo.

2. La segunda diferencia tiene que ver con el objetivo de Guillén, que aunque tome el argumento de Cervantes, quiso ofrecer una luz nueva: Para ello crea los antecedentes, hace más compleja la intriga y perfila la caracterización psicológica de los personajes. No sólo Anselmo sino también Lotario se salen de lo corriente ${ }^{23}$.

3. Pero posiblemente la modificación fundamental está en el reparto de la responsabilidad: Siendo Anselmo el principal responsable, en la Comedia, también Lotario es causante del infortunio desde su equivocación manipuladora al sacrificar el amor a la amistad.

\section{III.1.C. Temática guilleniana: amor, amistad y dominio}

1. Tres son los conflictos que Guillén entrecruza: el Amor frente a la Amistad, las contradicciones del Honor, y los abusos del Poder, tanto público como privado ${ }^{24}$.

2. En el tema del Amor, en un análisis superficial cabe pensar equivocadamente que El curioso impertinente plantea de hecho la prevalencia de los amores adúlteros sobre los del matrimonio; pero el matrimonio final legaliza aquella irregularidad, ocasionada por errores.

${ }^{23}$ VICENTE GAOS, Anotaciones a su edición de El Quijote, Madrid 1987, vol. I, p. 656 , n. 35b: Observa que el que un hombre "perdido de amores» renuncie al matrimonio antes que a la frecuencia de trato con un amigo como dice Anselmo, resulta un tanto extraño.

${ }^{24}$ J. OLEZA, loc. cit. p. 16: Los tres temas se juegan sobre un mismo terreno, el de la condición de la mujer en una sociedad cuasifeudal. 
En cuanto a la Amistad, se ha visto como un montaje por el que podemos acercarnos mucho a las relaciones humanas, especialmente a la de la amistad frente al amor ${ }^{25}$.

3. El tema del dominio, es una reflexión sobre personas que se dicen amigas, cómo se manipulan una a otra: Hay una subordinación social y económica de Lotario a Anselmo, aunque parezca una amistad entre iguales. Guillén presenta el abuso del dominio de Lotario respecto al amor, decidiendo por Camila con quién tiene que contraer.

\section{III.1.D. Género dramático: Comedia. Los «apartes»}

1. Guillén es un gran poeta dramático y así la estructuración de El curioso impertinente se califica de magistral ${ }^{26}$. Hay asimismo sabiduría en la psicología de los comportamientos de sus personajes, desde el planteamiento inicial ${ }^{27}$.

2. Quiso Castro, a partir de un relato trágico escribir una obra teatral que, aunque con acciones dramáticas, tuviera un desenlace abierto a un porvenir feliz ${ }^{28}$.

Se trata de una tragicomedia, nueva mezcla barroca de géneros, con ingredientes de comedia ciudadana de capa y espada y un final de tragedia en que la muerte de Anselmo permite que el amor de Lotario y Camila termine en boda ${ }^{29}$.

3. Limitado por las reglas del decoro, el dramaturgo utiliza las posibilidades del parlamento y del silencio, destacando el uso superabundante del «aparte» lenguaje específicamente escénico, importan-

${ }^{25}$ Y. PELLÍN, Entrevista con la autora de la versión teatral, «Cuadernos Pedagógicos 23», de la Compañía Nacional de Teatro Clásico, p. 37: «El amor está presente en el texto pero sobre todo lo está la amistad, y las pruebas a las que la sometemos: qué somos capaces de pedirle a un amigo que haga por nosotros».

${ }^{26}$ FALIU-LOBATO, loc. cit. p. 30: La lucha ambigua de los amantes constituye un elemento escénico tan interesante que sin duda al leer la Novela atrajo la atención del técnico del espacio teatral que era Castro.

${ }^{27}$ Y. PALLÍN, Entrevista, loc. cit. p. 36: Se ha subrayado asimismo la sensualidad de la Comedia, al lado de otras obras del Siglo de Oro en que los personajes están pintados de una manera más convencional.

${ }^{28}$ FALIU-LOBATO, loc. cit. p. 35. Se advierte el tono de comedia ya desde el marco escogido para el primer acto sin que lo impida un desenlace trágico.

${ }^{29}$ J. OLEZA, loc. cit. p. 16: La hibridez barroca es tan completa que la muerte trágica de uno de los protagonistas es compatible con la comicidad y que lo que comienza en comedia pura, deriva ya en el Acto III hacia la tragedia para volver con el desenlace, a la comedia. 
te recurso del Siglo de Oro con el que el autor nos hace participar en los procesos emocionales de los personajes ${ }^{30}$.

\section{III.2. Dramatis personae}

La Comedia altera sustancialmente el diseño cervantino, añadiendo nueva acción y nuevos personajes (Duques, Torcato, Culebro, Ascanio padre de Camila, Camarero) que muestran la creatividad y los propósitos del valenciano. La ampliación de la lista de los personajes cumple además la función de adensar el enredo, objetivo general de la comedia nueva ${ }^{31}$.

\section{III.2.A. Los protagonistas}

\section{III.2.A.a). Anselmo}

Galán muy rico, cuya familia crió a su lado a Lotario, estableciéndose entre ambos profunda amistad e identidad ${ }^{32}$. Ausente unos años, al llegar a Florencia se enamora fulminantemente de Camila, pidiéndola como esposa para él su amigo Lotario, que sólo después de la boda le confiesa que era con la que se iba a casar.

Aunque tiene todo para ser feliz, trata de sobrepasar sus límites y los de los demás. Empuja a su amigo Lotario a que le sea desleal, y a su mujer a que le sea infiel; y en el colmo del intervencionismo los casa a su muerte. Castro modifica sustancialmente la condición del personaje, dotándolo de lógica en su curiosidad ${ }^{33}$.

${ }^{30}$ Y. PALLÍN, Fabricadores de su deshonra, en "Cuadernos Pedagógicos 23», de la Compañía Nacional de Teatro Clásico, p. 15: En algún momento, un personaje, apartándose o desviándose del resto, puede hacer un comentario en voz alta, destinado al público, que no es oído por el resto de personajes. Gracias a esas ventanas de la mente, el espectador conoce cambios delicados, sutiles vacilaciones y peligrosas estrategias. El verdadero acierto de los apartes en esta pieza está en que nos hacen conocer sus entresijos.

${ }^{31}$ RUIZ RAMÓN, De algunos principios metodológicos, en Estudios de teatro español clásico y contemporáneo, Madrid, 1978, pp. 21-43: Difícilmente es posible la complicación y el enredo con tres protagonistas; son necesarios obstaculizadores, y un tejido de episodios que exigen agentes variados.

${ }^{32}$ GUILLÉN DE CASTRO, El curioso impertinente, acto I:

$Y$ fuimos Anselmo y yo/ con una igualdad extraña,/ nacidos en una cuna,/ criados en una cama;/sola un ama nos dio leche/ que no quisimos tomalla/ de los pechos de otras amas./Fuimos los dos a una escuela,/ tuvimos los dos un alma.

${ }^{33}$ GARCÍA LORENZO, loc. cit. p. 154: «El marido, que en Cervantes únicamente quiere morbosamente probar a su esposa, tiene en la comedia de Guillen una razón 


\section{III.2.A.b). Lotario}

A pesar del título de la Comedia, Lotario es el héroe de Castro ${ }^{34}$.

En la Comedia Lotario es también causante de lo que sucede: asimismo indiscreto, yerra imprudentemente al ceder la novia a Anselmo, sintiéndose deudor de su amigo. La despreocupación por los derechos y gustos naturales de Camila, que en Cervantes se atribuía a Anselmo, corresponde en la Comedia también a Lotario, al entregarla sin tener en cuenta su voluntad.

Es el hombre de las cesiones: Además de entregar impulsivo a su novia, cederá también a la desaforada pretensión de su amigo de que seduzca a la que ya es su esposa. Cede irreflexivamente a su sospecha celosa denunciando a Anselmo la infidelidad de Camila. Y finalmente cede a casarse con Camila, muerto ya su amigo.

\section{III.2.A.c). Camila}

Cambio trascendental es el que afecta a Camila, enamorada de Lotario, y entregada a Anselmo, con la presumible frustración amo$\operatorname{rosa}^{35}$.

La Camila guilleniana, exhibicionista del honor, acalla sus quejas (expuestas en apartes escénicos) en aras de su dignidad. Llevada a una obediencia aparentemente «honorable» se deja hacer ${ }^{36}$. Pero tal honor es precario: Se exhibe como ejemplo de esposa contenta, cuando ya ha traicionado a su marido, cuando la Duquesa se queja de su matrimonio. Y hasta en su pelea con Leonela, cómplice de su infidelidad conyugal se acoge absurdamente a su dignidad ya perdida.

mucho más lógica para entender su conducta: desea saber si aquellos afectos anteriores a su matrimonio siguen o no existiendo entre Camila y Lotario».

${ }^{34}$ FALIU-LAUTREC «Formas vicariantes de un tema recurrente: El curioso impertinente (Cervantes y Guillen de Castro)», Criticón, 30, 1985, nota 10: «Véase en mi tesis doctoral Guillen de Castro, Toulouse-Lille, 1984, el capítulo dedicado a El curioso impertinente. Añadiremos que, aunque la importancia de un personaje no se mida por los versos que pronuncia, hay que señalar el reparto siguiente: Anselmo, Lotario, Camila: Acto I, 207, 292, 82. Acto II: 393, 390, 318. Acto III: 125, 180, 198.»

${ }^{35}$ Y. PALLÍN, Entrevista, p. 36: Guillén construye la relación entre Camila y Lotario y su cesión a Anselmo, lo que hace que esta mujer sea una verdadera víctima de uno y de otro y víctima también de la codicia de su padre

${ }^{36}$ I. ARELLANO, loc. cit. p. 85: No hay apenas parlamento en que Camila no insista en su honor, motivo que según declara, rige toda su conducta. 


\section{III.2.B. Personajes secundarios}

\section{III.2.B.a). Leonela}

Una de las ampliaciones importantes de Castro es el papel de Leonela desempeñando la función de resorte dramático determinante, al mismo tiempo que adquiere cometido necesario en el diálogo con su ama ${ }^{37}$; han crecido juntas y representa su doble instintivo por cuyo medio el mal se insinúa en ella. Es entrometida, poco respetuosa con su señora a la que da lecciones; cuando Camila, llevada de la ira le da una bofetada, no le importa chantajearla vengándose.

\section{III.2.B.b). Culebro}

El gracioso de la Comedia es un matón, tipo del «miles gloriosus» o soldado fanfarrón. Se enamora de Leonela, poniendo manos a la obra $^{38}$. Su papel es figura definida y no aquella sombra sin nombre que era el amante de Leonela en Cervantes. Culebro divierte con sus chistes, italiano macarrónico, juegos de palabras, apuntes obscenos.

Pero ni el papel de gracioso de Culebro, ni el de confidente de Leonela constituyen lo más importante; lo más trascendente es la acción vicaria encomendada a la pareja ${ }^{39}$.

\section{III.2.B.c). Torcato}

Acompañante parásito de Lotario, preocupado de la amistad de éste con Anselmo, intenta obstaculizarla. Ilustra una modalidad torpe de amistad, ligándose así a uno de los temas centrales. Choca con Culebro; sólo que éste personaje está construido con mejor material humano.

${ }^{37}$ FALIU-LOBATO, loc. cit. p. 31: Al desaparecer el narrador intérprete de los pensamientos y sentimientos de Camila, ésta tiene que comunicarlos al público a través de las confidencias hechas a Leonela.

${ }^{38}$ COMPAÑÍA NACIONAL DE TEATRO CLÁSICO, loc. cit. p. 22: Castro construye un personaje divertido, bastante honesto y con sentido común. No oculta lo que es; tiene una forma de entender la vida que tiene que ver con el sentir español y con el humor y la gracia napolitana.

${ }^{39}$ I. ARELLANO loc. cit. p. 90: En el plan de la comedia la pareja de Leonela y su amante cobra una importancia notable, y revela con medios estrictamente teatrales (una acción representada por otros personajes) sentimientos de los protagonistas. 


\section{III.2.B.d). Ascanio}

Padre de Camila, aparece en el I. ${ }^{\circ}$ Acto para no salir más; aunque iba a casar a su hija con Lotario, como el cambio trae consigo más dinero, dispone contento la distinta boda que aquel le propone.

Viejo ambicioso y manipulador contribuye al tono cómico como «senex avarus», a la vez que subraya la marginación (nada cómica ésta) de Camila, cuyo cambio de matrimonio dispone, sin preocuparse de sus deseos o sentimientos.

\section{III.2.B.e). El Duque}

Máximo gobernante de Florencia, al que nunca vemos gobernar, si no es en el desenlace de la obra, que posibilita un final feliz.

Los Duques ejemplifican otra modalidad de relaciones matrimoniales defectuosas por la infidelidad del Duque y los celos de la Duquesa que no cesa de vigilarle.

Los amoríos, cortejos, rondas y celos del Duque complican el entorno de Camila y Lotario.

\section{III.2.B.f). La Duquesa}

Corresponde a las infidelidades de su marido con escenas de celos y espionaje; trata de mostrar que los engaños de él y la respuesta de ella son la forma social de llevar el matrimonio con una doble vida. Da a las demás recetas conyugales, pero ella no sigue sus propios con$\operatorname{sejos}^{40}$.

\section{III.2.B.g). Camarero}

Al servicio del Duque vive en paralelo con su señor al que adora. Le gusta de él su personalidad calavera; le intenta servir en bandeja todos sus caprichos y ayudarle a conseguirlos. Aborrece a la Duquesa porque entorpece los planes de su amo.

${ }^{40}$ COMPAÑÍA NACIONAL DE TEATRO CLÁSICO, loc. cit. p. 21: Ante el acoso al que el Duque somete a Camila su dama, la Duquesa mira para otro lado y se duerme, como una madre que participa con su inactividad permitiendo que su compañero «juegue» con su hija. 


\section{III.3. El primer acto}

La utilización de la fuente cervantina no comienza hasta el Acto II. Castro construye todo el primer Acto como algo totalmente nuevo que contiene todos los elementos básicos que marcan la versión guilleniana: invención clave que presenta una relación amorosa previa de Lotario con Camila y la descabellada cesión que éste hace de su novia a su amigo Anselmo que se ha enamorado repentinamente de ella. Los celos patológicos de la Novela, celos irracionales sin causa, aquí van a tener una explicación.

\section{III.3.A. Cuando se levanta el telón}

El Acto se abre con una ronda nocturna en la calle ante el palacio de los Duques de Florencia, con una serenata de unos músicos cómicos españoles contratados por Lotario para acompañar a un poema que ha escrito en honor de Camila dama de la Duquesa.

(Los Músicos cantan este romance:)

Amor que me quita el sueño

para rendirme sin él...

(Abren la ventana y aparecen el Duque y la Duquesa de Florencia, Camila dama y el camarero)

(Lotario a Torcato en la calle)

- ¿Qué decís del romancito?

- ¿Es vuestro?

- ¿Qué enamorado no es poeta?

\section{III.3.B. Loa}

1. Se perfila ya el horizonte de una comedia, alejándose de la versión trágica cervantina. A este propósito después de ponderar la fama de Lope de $\mathrm{Vega}^{41}$, se ha introducido un fragmento de teoría dramática de la fórmula nueva que orienta hacia la comedia, al

${ }^{41}$ LOPE DE VEGA, La dama boba: En ella incluye las «Comedias de don Guillén de Castro", entre los libros de la culta Nise, lo que muestra la mutua estima con que se corresponden. 
tiempo que se hace referencia a los autores latinos padres de la misma $^{42}$.

En esta comedia Guillén da un paso en la decidida inserción en su dramaturgia de un género nuevo, el de la tragicomedia urbana de capa y espada en el movimiento de la Comedia nueva ${ }^{43}$.

\section{III.3.C. Acción principal: enamorados en espera}

1. La serenata de Lotario pretendiente de Camila desde hace tres años, termina con suspiros en la recatada enamorada.

(Camila: -Del tierno amor / con que a mi Lotario adoro,/ de alegre y contenta lloro.)

(Vanse los músicos y los que oían entranse de la ventana y Camila cerrándola, dice aparte:

(-Con qué amoroso cuidado/ he quedado, aunque tu amor/ disimulo ;Ay, santo honor!)

2. En la calle Lotario, comenta sus amores con su acompañante Torcato, al mismo tiempo que le habla de su amigo Anselmo, su alma gemela cuya llegada aguarda para casarse ${ }^{44}$.

${ }^{42}$ GUILLÉN DE CASTRO, loc. cit. acto I: (El Duque y el Camarero en una ventana)

- ¿Y quién son?

- Señor, representantes españoles./En Roma han representado/en Nápoles y en Milán,/ pero no es mucho que asombre / con las comedias de un hombre/ monstruo de naturaleza.

- ¿Es Lope?/ Por el nombre que le has dado/ es de todos conocido.

-Que parezcan en España lbien, pero que acál asombren es cosa extraña,/ adonde Plauto y Terencio/ tan grandes amigos tienen.

${ }^{43}$ J. OLEZA, loc. cit, p. 16: Guillén todavía no había ensayado este género, y lo hace en esta obra en que la actitud barroca es tan completa, que la muerte trágica de uno de los protagonistas es compatible con la comicidad arrufianada de Culebro.

${ }^{44}$ GUILLÉN DE CASTRO, loc. cit. acto I: (Lotario a Torcato)

-Ya la ventana han cerrado./ Amigo, mi sol se ha puesto.

-Pues este sol que se puso / se pondrá en tus brazos presto

- Sé que ha procurado/ conclusión al casamiento,/ con su padre

- ¿Y en qué está?

-Yo soy el que lo entretengo/ por la obligación que tengo/ a Anselmo, mi grande amigo,/ a quien de Génova espero.

-No es cordura el dilatar/ cosa que se estima tanto.

-No dejaré, aunque la pierda,/de cumplir mi obligación.

- ¿Luego estimas su amistad / más que el amor de Camila?

- Sí por cierto. 


\section{III.3.D. Acciones secundarias: Duque, Torcato y Culebro}

1. La acción secundaria amplia la estructura de enredo de la comedia, con multiplicación de peripecias, equívocos y maquinaciones.

2. La presencia del Duque inicia los obstáculos al amor y a la amistad: El Duque está enamorado de Camila a la que en vano asedia con rechazo de ésta refugiada en su honor, sin que la Duquesa pueda evitar estar celosa ${ }^{45}$. El ayuda de cámara, que acompaña al Duque en su aventura como más corrido y experimentado es la voz que le aconseja y anima.

3. La acción secundaria se extiende en un episodio picaresco que introduce a Culebro.

- ¿No habéis conocido / por la pinta esta figura?/ ¿no basta el ver que traigo / poco pelo y mucha pluma? /y que asi estoy en Italia, donde soy/bien venido y mal pagado?

No puede faltar el relato autobiográfico de sus andanzas de soldado $^{46}$.

El encuentro imprevisto de Anselmo recién llegado con Culebro el espadachín español al que alguien ha encargado que le dé una cuchillada, entra en el tema de la amistad:

Culebro ante el brío de su víctima, desiste del encargo pidiéndole un dinero. Anselmo que quiere saber el nombre del mandante, al confesarle Culebro que se llama Lotario, queda anonadado; pero pronto se descubre el engaño y su implicación, cuando al pasar por allí Torcato le señala Culebro como el autor del encargo ${ }^{47}$.

${ }^{45}$ I. ARELLANO, loc. cit. p. 82: Los amoríos, cortejos y rondas del Duque complicarán igualmente el enredo con celos en torno a las relaciones de Camila y Lotario.

${ }^{46}$ GUILLÉN DE CASTRO, loc. cit. acto I:

- A mí me llaman Culebroly tengo casquivano el celebro./Y así, en diez años de Flandes, / herí a siete y maté a tres./Pasé a Nápoles, y en él,/ por no sé qué niñerías,/molí a palos a un soldado./Embarqueme, y de hambre muerto,/asi en Florencia he llegado./Y vi un gentil hombre/ y dijome que me daríal chento escuti en plata pura,/porque hiciese una aberturalen vuestra cara.

- ¿En la mía?

- ¿No sois Anselmo?

${ }^{47}$ I. ARELLANO, loc. cit. p. 82: Torcato, amigo ambiguo $y$ protegido de Lotario, comienza una serie de maquinaciones para impedir que éste reanude su amistad con Anselmo, lo que explica el encargo de la cuchillada a nombre de Lotario 


\section{III.3.E. A Anselmo, Lotario le cede su novia}

1. Anselmo ausente tres años de Florencia, ha llegado desde Génova. Sin descanso tiene prisa por ver a Lotario, actitud con la que se jacta de su amistad ${ }^{48}$.

Pero Anselmo a su paso ha reparado en Camila, dama que acompaña a la Duquesa a la iglesia de la que se enamora fulminantemen$\mathrm{te}^{49}$.

2. Al encontrarse con Lotario, le da cuenta de su flechazo amoroso, quien percatándose de que se trata de su amada Camila, sin manifestárselo, se ofrece a pedirla por esposa para él a Ascanio su padre $^{50}$, sin ni siquiera dar cuenta a ella, lo que provocará la amarga queja de Camila a la que nada se ha preguntado ${ }^{51}$. Tampoco al padre de Camila, feliz del cambio ante la fortuna del nuevo, parece importarle la voluntad y sentimientos de Camila ${ }^{52}$.

${ }^{48}$ GUILLÉN DE CASTRO, loc. cit. acto I:

- ¿Y no es mejor/ descansar? Mira, señor,/ qué de postas has corrido.

- Pensando que a Lotario iba sirviendo, /quisiera venir volando.

- Con razón os llaman todos/ amigos por excelencia.

${ }^{49}$ FALIU-LOBATO, loc. cit p. 12: En Castro los «dos amigos» se muestran de la misma condición y gustos, igualdad que hace ver al espectador el previsible enamoramiento de Anselmo, prendado también de Camila: Si Lotario se ha enamorado de Camila, es probable que su amigo identificado en sus inclinaciones haga lo mismo.

${ }^{50}$ GUILLÉN DE CASTRO, loc. cit. acto I (Lotario encuentra a Anselmo)

- ¿Adónde con tanto brío?

- En este templo entraba/ pero entre aquellas/ damas bellas /una ví...

- ¿La que junto a la duquesa iba?

(Lotario: Camila es ésa. ;Ay, Fortuna!)

-Pudo tanto, que me vi / ciego y loco

- iYo soy muerto!

-Escucha...¿Esa dama conoces?

- Deuda de los duques es/ de Nápoles ha venido/habrá tres años.

(Lotario: ;Ay de mí!)

-Si tú gustas, de mi mano/quiero casarte con ella.

(Lotario: Muerto estoy.)

${ }^{51}$ I. ARELLANO, loc. cit. p. 84: Nótese que la ignorancia de los gustos y derechos naturales y sociales de Camila, que en Cervantes correspondía a Anselmo, corresponde en Castro fundamentalmente a Lotario.

${ }^{52}$ GUILLÉN DE CASTRO, loc. cit. acto I (Lotario y Ascanio)

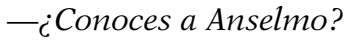

- Sí. ¿Quién no conoce su nombre?

-Pues ése ha de ser esposo de Camila.

-No hay hombre en toda Florencia tan rico./ Por su esposa te prometo a mi Camila. (Lotario: ;Ah, poderoso interés, / y qué presto hiciste efeto!)

(Lotario: ¡Ay, Camila! Tú dirás que he sido amante traidor/mas perdona, que el amor de mi amigo pudo más.) 
3. Sólo una vez celebrada la boda, Lotario informa a su asombrado amigo que se ha casado con la mujer que él amaba:

-Lotario, ino me dijeras/con qué mujer me casaba!/

Este descabellado gesto de Lotario muestra que posiblemente ni su amistad ni su amor son auténticos ${ }^{53}$.

\section{III.3.F. Se acuerda casar a Camila}

1. Ascanio familiar de la Duquesa, le ha dado cuenta del nuevo pretendiente $e^{54}$, la que ve con agrado la celebración de aquel matrimonio ${ }^{55}$, siendo ella la que propone a Camila la boda, con sobresalto del Duque ${ }^{56}$.

Ésta aunque enamorada de Lotario que la corteja desde hace tres años, se muestra dispuesta a aceptar el marido que le dispongan, mostrando con fingida dignidad desinteresarse por saber su nombre ${ }^{57}$.

${ }^{53}$ M. GARCIA MARTÍN, Cervantes y la comedia española en el siglo XVII, Salamanca 1980, p. 65s.: «acción de todo punto insensata e inconcebible en los presupuestos sociales de los siglos XVI y XVII». F. AYALA en Los dos amigos, loc. cit.: es inverosímil y excesiva, pues supone un sacrificio gratuito; GARCÍA LORENZO en El teatro de Guillen, p. 154, lo explica por la importancia de la amistad en el teatro de Castro.

${ }^{54}$ GUILLÉN DE CASTRO, loc. cit. acto I: (Duquesa, Duque y Camila)

-Duque, apercebios a honrarla Camila, a quien su padre quiere casar.

(Duque: ;Ay del alma que la adora!)

(Camila: Ya llegó el dichoso día de ser mi esposo Lotario,/ que es alma mía.)

(Duque: Bueno es tener esperanza.)

(Duquesa: No es malo quedar sin celos.)

${ }^{55}$ Era norma en las costumbres feudales proveniente del Derecho Germánico que los nobles obtuviesen de sus señores la autorización de su matrimonio.

${ }^{56}$ GUILLÉN DE CASTRO, loc. cit. acto I (Salen Duquesa y luego Camila)

- ¿Qué es de Camila?

-Ya viene.

(Duque: Esta mujer / que tan sin alma me tiene)

-Camila tu padre quiere casartel y de ti quiere saber / si te ofende o si te agrada en esto.

-Siendo mujer,/ hija suya, y tu criada,/ ¿qué tengo de responder,/ o qué voluntad tendré,/ sin la vuestra?

(Duque: Muero de pena. ¿Qué haré?)

- ¿No me preguntas con quién? basta.

-Yo, señora, ¿para qué?/ Si es que manda Vuestra Alteza/ y mi padre; para míl eso

(Camila: Ya sé que Lotario es, / a quien con el alma adoro.)

${ }^{57}$ I. ARELLANO, loc. cit. p. 86: Camila en un aparte explica su falta de interés en el nombre del marido pues está segura aunque equivocada, de que es su amado Lotario el que la ha pedido. 
2. En la secuencia inmediata, se ofrecen en el palacio los consejos de la Duquesa a Camila y al mismo tiempo las asechanzas amorosas del Duque al amparo de los regalos que le hacen, oponiendo Camila su resistencia y honor del que una vez más hace alarde ${ }^{58}$.

3. El Acto primero termina con una cuádruple lamentación; significativamente Anselmo no se lamenta con lo que aparece como el triunfador del primer Acto.

(Lotario: ;Mil veces soy desdichado!)

(Duque: ;Agora estoy más perdido!)

(Camila: ¡Ay honra! ¿A qué has obligado?)

(Lotario: ¡Ay amistad! ¿Qué has perdido?)

\section{III.4. El acto segundo}

Empieza ahora la Novela de Cervantes, relato que como se ha dicho ha sido «reescrito» por Guillén. Los elementos básicos que marcan esta versión van a conducirnos a lo largo de la comedia ${ }^{59}$.

El Acto segundo más breve que en la Novela ${ }^{60}$, se centra en el impertinente deseo de Anselmo, y en su puesta en práctica por Lota-

${ }^{58}$ GUILLÉN DE CASTRO, loc. cit. acto I: (Duquesa a Camila)

-De mis celos engañada/ aprendo a desengañar./ Tú, si quieres vivir en paz/ ni los pidas ni los des.

(Camila al Duque)

- ¿Con oro quieres comprar?/ ¿Tan poco estimas mi honor?

- Camila, ¿qué haré, si me abraso/ en tus ojos y en tu amor?

${ }^{59}$ Y. PALLIN, Entrevista, p. 36: Viendo como un autor adapta a su obra las decisiones que otro autor tomó, encontramos ahí su verdadero estilo, mucho más que cuando trabaja con un tema original.

${ }^{60}$ I. ARELLANO, loc. cit. p. 87: El espacio del segundo acto es en secuencias mucho menor en la Comedia. En la novela son 10 páginas; y en número aproximado de palabras: 760 en la comedia frente a 3.750 en la novela, cinco veces más.

${ }^{61}$ GUILLÉN DE CASTRO, loc. cit. acto II: (Anselmo y Lotario)

-Una locura, una fuerzal me descompone y me ciega./Celos me abrasan el alma,/sin tener otra ocasión,/ porque ella es honrada,/ es recogida, recatada.

-Eso, perdóname, Anselmo,/ más parece impertinencia que celos.

-No está en mi mano./Pienso que podría no ser buena./ Mataráme esta congoja,/si con curiosa experiencia/no acrisolo su valor./Ésta, sólo otro yo puede hacerla, /que eres tú, Lotario, amigo./ Que si de ti se resiste,/ a quien quiso, podré vivir contento.

- ¿Búrlaste Anselmo o deseas/hacer las pruebas en mí?/ Que tan curiosa impertinencia les locura manifiesta.

- Si tú no quieres/ya estoy resuelto en buscarl quien lo haga.

- Basta, no digas más./A voluntad tan resuelta,/obedecer y callar. 
rio, siguiendo, en líneas generales el argumento cervantino, terminando con el rendimiento de Camila.

\section{III.4.A. Se pone en marcha la impertinente prueba}

1. Como un anticipo abre el Acto Camila casada, confesando a su criada Leonela que quiere a Anselmo su marido, olvidada por su honor de sus amores con Lotario. Pero el Acto se centra en la impertinente curiosidad título de la obra. A su vez Anselmo con poco juicio y mentalidad machista, reclama la presencia continua de su amigo en su casa, sin contar con su esposa, mientras Lotario excusa sus ausencias: en la Novela elude las visitas a los recién casados por «discreción», mientras que en la Comedia dice hacerlo para olvidar su amor.

2. Anselmo que ha dado en recelar de su esposa, propone a Lotario su amigo que intente seducirla. Lotario despés de haberse esforzado en hacerle ver lo absurdo de tal propuesta, cede finalmente ante la intención de Anselmo de pedírselo a otro ${ }^{61}$. Al haberle confesado Lotario que Camila había sido su novia, quiere Anselmo que sea precisamente éste el que tiente a Camila ${ }^{62}$.

Muy poco de los larguísimos discursos que con todo género de argumentos Lotario rebate las explicaciones de Anselmo, permanece en la escena ${ }^{63}$; tal morosidad retórica sería intolerable en el proceder más dinámico de la comedia ${ }^{64}$.

3. Anselmo pone en marcha la descabellada prueba, ordenando a su esposa que atienda a su amigo Lotario que permanecerá en la casa, mientras él se ausenta.

Los «apartes» en que se expresan son significativos.

(Camila: ;Qué notable confianza de amistad!)

(Lotario: ;En qué estacada me veo!)

(Camila: Mi valor queda conmigo.)

(Anselmo: Para escuchar si mi amigo/prueba a lograr mi deseo/lugar me dará esta llave.)

${ }^{62}$ Y. PALLÍN, Entrevista, p. 36: Para ello Guillén construye toda la relación de noviazgo entre Lotario y Camila, que dota de lógica a la acción.

${ }^{63}$ I. ARELLANO, loc. cit. p. 76: La solicitud e insistencia de Anselmo ocupa 3 páginas, la respuesta argumentada extensamente de Lotario 7 páginas.

${ }^{64}$ FALIU-LOBATO, loc. cit. p. 44: En el diálogo de Anselmo y Lotario ha desaparecido toda la elaboración teológica y moral y los ejemplos aducidos por Lotario. 


\section{III.4.B. Fingimiento al descubierto}

1. Lotario se halla frente a Camila sin atreverse a llevar a cabo el asalto. Los «aparte» prosiguen mostrándonos sus actitudes interiores.

(Camila y Lotario)

(Lotario: Como que duermo he de hacer,/ y dejaré de pensar,/ quizá, con dejar de ver.)

(Camila: A no hablarme se ha forzado,/por no verme se ha dormido:/ mucho obliga a ser querido / un hombre que es tan honrado.

2. Cuando Anselmo vuelve, Lotario le cuenta que su mujer ha resistido el asedio que no ha realizado.

(Anselmo: Bien vi que el intento míolemprendió con gusto poco./ Ni una palabra le ha hablado.)

- ¿Que hay de nuevo en mi quimera?

-Comencé a hablarla, /fuése y diome las espaldas por respuesta.

-iAh, Lotario!/Ya he visto lo que ha pasado,/ porque este engaño temil y a la puerta/ me puse, donde he podido ver./ Mal mi amistad has pagado.

-Anselmo, pues culpado estoy./ De servirte sin engaño/ de hoy palabra te doy.

3. Anselmo, para facilitar el asedio, dice tener que marchar a Pisa en una misión del Duque, pero no deja Florencia, confíando a Culebro secretamente que lo hallará en casa de Lotario gozando de cierta dama, a donde le puede llevar cualquier mensaje ${ }^{65}$.

\section{III.4.C. Va de veras. Asechanzas cortesanas que estimulan}

1. Cuando se inicia el asalto sin ficción, se vislumbra la verdad disimulada por Camila ${ }^{66}$. Leonela con lenguaje desvergonzado actúa como doble de su $\mathrm{ama}^{67}$.

${ }^{65}$ GUILLÉN DE CASTRO, loc. cit. acto II: (Anselmo y Camila)

- El duque me lo ha mandado,/con que a Pisa tengo de ir./ Pero Lotario vendrál a mirar por vuestro regalo.

- ¿Pues con otro que con vos/en vuestra ausencia he de estar?/ Mas como es mozo y galán,/ y yo nueva en vuestro amor,/recelo del qué dirán.

-Pues divierte ese cuidado,/y recíbele en tu estrado, /y convidale a tu mesa.

${ }^{66}$ GARCÍA LORENZO, loc. cit. p. 154: véase nota 33

${ }^{67}$ GUILLÉN DE CASTRO, loc. cit. acto II: (Leonela Y Camila)

- Estarás muy afligida/de que tu esposo ha partido.

-No siento el haberse ido,/sino que Lotario aqui ha de quedar, /y conmigo ha de comer. 
2. Se percibe una situación embarazosa y ambigua en que Lotario y Camila se ven turbados, expresándolo en «apartes».

(Lotario en una silla y Camila en una almohada)

(Camila: ¡Qué de veces me ha mirado / y qué de veces ha huido de verme!)

(Lotario:; Qué arrepentido/ estoy de haber llegado!)

(Camila: ¡Qué ansias, qué penas!)

(Lotario: ¿Cerraré los ojos?)

Lotario simula dormirse ${ }^{68}$, dando ocasión a las añoranzas amorosas $^{69}$.

3.-Una visita del Duque a Camila es ocasión de otras implicaciones $^{70}$. Cuando éste intenta sin éxito seducir a Camila, los celos se despiertan en Lotario ${ }^{71}$, que se enfrenta en defensa del honor de Ca-

— ¿De eso, señora, te pesa?/Pues él le ofrece la mesal ofrécele tú la cama.

(Sale un Paje)

- Lotario pide licencia. casa.

- ¿Pues Lotario ha menester licencia?/Después que él es ido/ mandáis más en esta

${ }^{68}$ FALIU-LOBATO, loc. cit. p. 15: En la Novela el seductor era más directo. En la Comedia Lotario más tímido utiliza la traza del sueño frecuente en Castro, para confesar indirectamente un amor que no tiene el ánimo o derecho de proclamar.

${ }^{69}$ GUILLÉN DE CASTRO, loc. cit. acto II: (Camila Y Lotario)

- ¿Tenéis sueño?

-No, señora, pensaba/ que atrás en el tiempo volvía,/ y gozaba del mismo díal que en tus ojos me abrasé.

-No digas más, que esas cosas/ sueño han sido y sueños son.

-Di, señora,lfuego han sido y fuego son.

- ¿Son burlas esas quimeras?

- Burlando las comencé,/pero ya muero, y no sél si son burlas o son veras.

-Lotario, corrida estoy/ de tu infame proceder./ iDísteme para mujer/ y búscame para amiga!/

(Lotario: Con este honrado desdén me abrasa.)

${ }^{70}$ COMPAÑÍA NACIONAL DE TEATRO CLÁSICO, loc. cit. p. 21: Marido infiel, vive en un círculo perverso de relaciones de pareja.

${ }^{71}$ GUILLÉN DE CASTRO, loc. cit. acto II: (Sale un Paje)

-El duque pide licencia. nor!

(Camila: Esto agora me faltó./ ¡Ay, cielos! que ha de costarme esta ausencia/;Ay, ho-

(Sale el Duque)

- ¿Con qué miedo os vengo a ver!

- ¿Es que me quejo yo/ del ausentarme el marido?

- ¿Ausente está? ¿Dónde ha ido?

- ¿Luego no se lo mandó/ vuestra alteza?

-No mandé tal. 
mila, haciéndo saber al Duque que él ocupa el lugar de su amigo Anselmo; el Duque le amenaza de muerte, pero Camila consigue aquietarlos.

\section{III.4.D. Representación vicaria: el cortejo de Culebro}

1. La acción picaresca se sitúa en la casa de Anselmo, porque Culebro se ha enamorado de Leonela a la que corteja.

Una aportación estructural importante de la comedia es la acción vicaria encomendada a Culebro y Leonela en disposición paralela a las escenas claves del asedio de Camila ${ }^{72}$. Se revelan con medios estrictamente teatrales (una acción representada por personajes), actitudes de los protagonistas que en la Novela el narrador podía revelar con su omnisciencia. Mientras Lotario acompaña a Camila, Culebro y Leonela mantienen un diálogo procaz que se refleja sobre los señores ${ }^{73}$.

2. Más tarde en nueva escena de cortejo, Culebro dispondrá con Leonela un encuentro, avance de la entrega de Camila y Lotario. El brevísimo diálogo entre Leonela y Culebro no puede ser más claro en esta función paralela que ilumina estas escenas ${ }^{74}$. La reescritura guilleniana alcanza, sus más precisas calidades en este diseño de la acción vicaria ${ }^{75}$.

(Camila: pues él debió de enviarlo /porque quiso a solas verme.)

-Yo, miedo de verme en tus ojos/ era sólo el que traía.

(Aparte Lotario: Estos celos me faltaban/ para abrasarme del todo.)

${ }^{72}$ I. ARELLANO, loc. cit. p. 89: En ellas realizan un tipo de representación que revela la verdad disimulada de las pasiones de los amos. El diálogo evitado entre los protagonistas se ha producido en un nivel más bajo (y más revelador) en sus representantes vicarios.

${ }^{73}$ GUILLÉN DE CASTRO, loc. cit. acto II: (Culebro y Leonela)

- Joya mía, yo te adoro.

-Y yo a ti te tengo amor.

-Pues encaja.

- Aún es temprano, soy doncella.

-Acaba, llega.

- Tuya he de ser.

-Yo soy tuyo.

${ }^{74}$ I. ARELLANO, loc. cit. p. 89: Culebro y Leonela, representan en ese crítico momento, según la regla del decoro dramático, una escena con crudas alusiones eróticas, reflejo simbólico de la realidad que afecta a Camila y Lotario.

${ }^{75}$ GUILLÉN DE CASTRO, loc. cit. acto II: (Leonela y Culebro)

- ¿Quién con ocasión más llanal de ti pudiera gozar!

- La que tengo es soberana.

- Vete y razones ataja.

-Otra pareja; ventaja/nos lleva, porque es mayor;/ quiero meterme en baraja.(Entran Camila y Lotario) 


\section{III.4.E. Carta de Camila y confidencia de su criada}

1. Camila entre dos fuegos de asechanzas siente la ausencia de su marido.

—iQué bueno queda mi honor,/perseguido y acosado /de este príncipe arrojado, /y de este amigo traidor!/Pues me roba quien me guardal bien será llamar a quien /dé más fuerza a mi flaqueza;/que no hay fortaleza lque sin alcaide esté bien.

Camila, al escribir a su esposo deja entrever todavía su resistencia.

"Si no venís luego me habré de ir a entretener en casa de mis padres, aunque deje sin guarda la vuestra, porque la que me dejasteis, mira más por su gusto que por lo que a vos toca. Camila.»

2. Pero Leonela, serpiente tentadora, cuenta a Camila que espera impaciente la respuesta, que su marido no ha salido de Florencia y que se encuentra solazándose con una dama.

-Muéreste por él, señora,/ mientras él te está ofendiendo.

-Pues cuando estoy defendiendo /su honor ime ofende con otro amor?/;Ah, traidor! ${ }^{76}$.

\section{III.4.F. Anselmo quiere más pruebas: joyas, poemas, celos}

1. Anselmo a pesar de lo que Camila le ha escrito y de que Lotario le dice que Camila enojada le ha tratado de traidor, insiste en nuevas estrategias $^{77}$. La prueba de los poemas es de la Novela y la tentación de las joyas la vemos en los más antiguos antecedentes literarios.

2. Pero el darle celos va a ser lo efectivo ${ }^{78}$. Anselmo esperando comprobar que nada queda del amor que un tiempo se tuvieron, hace creer a Camila que Lotario amaba ya entonces a Clori dama a la que dedicaba sus versos ${ }^{79}$.

${ }^{76}$ FALIU-LOBATO, loc. cit. p. 30: No se deben separar la heroína y la doncella que representa su doble instintivo por quien el mal se insinúa en ella.

${ }^{77}$ GUILLÉN DE CASTRO, loc. cit. acto II: (Anselmo y Lotario)

- Prueba si puedes rendirla con joyas. / Y compónle algún soneto./ Diréle que andas perdido/ de cierta Clori.

-Por Dios, que pasando vas/ de curioso a impertinente./¿Y no adviertes, /que si tú te fías de ella/ yo no me fío de mí?/ Mira que la tuve amor, /y que no es justo ponerme la pique de ser traidor.

${ }^{78}$ FALIU-LAUTREC, Formas vicariantes...loc. cit. p. 177: Si la Camila de Cervantes está enterada del carácter ficticio de Clori, la de Castro se pierde por los celos despertados por este engaño.

${ }^{79}$ GUILLÉN DE CASTRO, loc. cit. acto II: (Camila y Anselmo)

- Si habéis leído mi cartalella os dirá mi razón. 
Camila queda celosa remontándose a los tiempos en que Lotario la cortejaba.

(Camila: ;Que este traidor me engañase!)

Solo se calmará cuando éste le explique que es una ficción que le sirve para sus versos ${ }^{80}$.

\section{III.4.G. Rendimiento de Camila y engaño expresado en apartes}

1. Camila, despechada porque su esposo tiene una amante, ve a Lotario como su verdadero amor ${ }^{81}$.

Lotario al confesar a Camila cómo hizo el sacrificio de cederla a su amigo ante su fulminante enamoramiento, le confía el doloroso proceso que ha seguido su recuperación amorosa ${ }^{82}$.

-Probé después con la ausencia,/ a curar la voluntad. /Con forzarme a que te viera/ volvió a encender el fuego./A decírtelo empecél creciole tu resistencia/ y avivole tu desdén;/y ofreciéndose también lo del Duque,/ sentí agravios, tuve celos/ y di con la amistad al través. nací.)

(Camila: ¿Es hechizo o es locura?/Pero ya mía no soy:/para Lotario

-Lotario, venciste, yo estoy rendida./Di con el honor al través./ Tuya soy.

- ¿Y ésa es bastante ocasión/ de esos enojos? / Sé que a Lotario otra cosal le tiene ocupado el pecho./Con sus versos celebrada,/sirve a una dama cuatro años ha./ En esto ve si te engañas./

(Camila: Mas, iay cielos!/ ¿Cómo agora tengo celos?/¿Que cuando a mí me servía,/a otra mujer adoraba?/ Buena estoy/ metida entre dos traidores.)

${ }^{80}$ FALIU-LOBATO, loc. cit. p. 16: Cuando Anselmo insinúa que Lotario quiere a cierta Clori, ya no le mira sino como al amor perdido que tiene que reconquistar.

${ }^{81}$ GUILLÉN DE CASTRO, loc. cit. acto II: (Camila y Lotario)

(Camila: Enamorada olvidél y celosa me enamoro, /que amor que acabó en olvido,/si vuelve, comienza en celos)

(Lotario: Hablarela, que es en vano/ resistirme.)

-Cielo hermoso, temeroso /llego a ti.

-Quita, enemigo, /que siendo traidor amigo/ aun no eres leal amante. /En el tiempo que fingías/ que hasta mi sombra adorabas,/¿a otra mujer seguías?/¿Qué Clori es ésta, villano?

-Yo he fingido otro amor./Advierte que es tuya/ el alma deste soneto. /Pierde esa injusta sospecha.

${ }^{82}$ FALIU-LOBATO, loc. cit. p. 29: Camila logra hacer (es una evolución capital en la Comedia) que Lotario sacrifique ahora la amistad al amor y le explique de qué proyecto fatal fueron víctimas, confesión que provoca la rendición de Camila. 
2. Cuando al final del Acto segundo baja el telón, afloran en «apartes» los sentimientos de cada uno de los protagonistas en torno al engaño consumado, del que sólo el marido como suele ocurrir, no se entera.

(Anselmo: ;Qué seguro vivo ahora!)

(Camila: Está engañado)

(Lotario: Está ciego ¡Qué afrenta se ha procurado!)

(Camila: ;Ah marido desdichado!)

(Lotario: ;Ah curioso impertinente!)

\section{III.5. El acto tercero}

El Acto tercero sensiblemente más corto que los otros dos, es el camino hacia un final cómico-trágico sirviéndose de diversos enredos (escala de Culebro, representación de Camila y bofetada a Leonela) que corren al borde del descubrimiento.

El Acto concluye con un doble desenlace que se encuentra ya en la fuente cervantina. La rapidez recomendada por Lope en el Arte Nuevo, se relega al postrero y definitivo desenlace.

\section{III.5.A. Palabras aparentes y realidades ocultas}

Se abre el Acto con una apacible escena en el palacio en la que Camila se muestra como la perfecta casada, aunque la realidad sea muy distinta ${ }^{83}$.

Una vez más se despliega en «apartes» el acabado estudio psicológico de los sentimientos: el despecho del Duque, los celos y espionaje de la Duquesa, el enamoramiento de los amantes, y el engaño de Anselmo.

(Camila, Duque, Anselmo, Lotario y Duquesa)

${ }^{83}$ GUILLÉN DE CASTRO, loc. cit. acto III: (Duquesa, Camila a sus pies) - Tenéis de buenos casados/opinión notable.

(Camila: ;A cuántos tiene engañados/ en el mundo la opinión!)

-Y entre los dos /¿corren celos?

-Ni aun fingidos

-Ellos pierden los maridos./Yo, ni los sufro ni los dejo.

- Sin ellos, señora, estoy,/que, tomando tu consejo,/ni los tengo ni los doy. 
(Camila: El duque viene. Y con él/ viene el alma de esta vida. ¡Ay, mi Lotario!)

(Duque: ¡Ay, cruel/y bellísima homicida!)

(Anselmo: ;Ay, querida esposa fiel!)

(Lotario: ;Ay, Camila de mi alma!)

(Camila: ;Ay, Lotario de mis ojos!)

(Duquesa: ¡Qué necio mirar, qué enojos!)

III.5.B. La escala alevosa que confunde, enreda y descubre

1. Un incidente que pone a todos en vilo, desencadenará el desenlace: El episodio de la escala es recurso que Guillén sabe explotar. Han precedido aventuras de visitas nocturnas y goce a escondidas de Culebro y Leonela, acción vicaria de las ansias de Lotario y de la entrega de Camila.

(Culebro y Leonela)

-iQuién con ocasión más llanal de ti pudiera gozar!

- ¿Hay tal gusto como hallar/ aquí puerta, allí ventana?

-Entra a esconderte y espera.

— ¿Qué gusto al mío se iguala?/Subir por una escalera/ y bajar por una escala.

(Lotario y Camila)

_iAy, Camila! /El Duque, que persevera/ en tus amores, me mata. da estoy.

- Cuando toda tuya soy/¿con tan poca confianza/me tratas? Corri-

2. Torcato alerta al Duque de cómo ha visto en el claroscuro del alba, bajar a un hombre por una escala de la casa de Anselmo; éste celoso se apresta a rondar la casa de Camila ${ }^{84}$. Al ver al que desciende desde el balcón cree que es Lotario que ha pasado la noche con Camila ${ }^{85}$; y Lotario que también ha visto al de la escala piensa que es el Duque.

${ }^{84}$ I. ARELLANO, loc. cit. p. 88: La escena nocturna es significativa de la estructura progresiva de enredo con sus equívocos y suspicacias.

${ }^{85}$ GUILLÉN DE CASTRO, loc. cit. acto III: (Duque, y Camarero)

-Éstas las espaldas son/de la casa, y un balcón,/del antecámara es de Camila,/ y en él se pone la escala.

(Echan una escala y baja Culebro por ella) 


\section{III.5.C. La denuncia del celoso despechado}

1. Lotario celoso e impetuoso, a pesar de que Camila ya se le ha rendido, va a poner a Anselmo al tanto sobre la infidelidad de su esposa $^{86}$.

(Sale Anselmo con dos criados, vestidos de cazadores)

- ¿Está todo apercebido?

- Los caballos con sus sillas, /los perros en sus traíllas.

- ¿Que Lotario no ha venido?

(Sale Lotario)

-Lotario, ¿se os ha olvidadolel concierto para hoy?

-En otras cosas estoy/ desde anoche desvelado.

- ¿Qué cosas? Decid.

-Toda la noche he dudado/si os diría lo que os digo./Sabed que vuestra mujer/ se ha rendido a mis porfías./ Mira si tienes lugarl por dónde ver escondido/cómo me espera tu esposa/ en tu cama.

-Lotario, yo mismo la he de ver.

-Pues di que vas a cazarly vete luego a esconder.

2. Pero Lotario que luego ha sabido que el de la escala era Culebro que pasa las noches con Leonela, arrepentido de su despechada acusación, no puede menos de darle cuenta a su amada ${ }^{87}$.

(El Duque al Camarero)

- ¿No es Lotario?

- Sí, señor.

-iQue baja por la escala!

(Duque: ;Oh, alevoso!/ Camila mil veces mala.)

(Vanse el Duque y el camarero, y quédase Lotario)

(Lotario: ¿Qué es esto?/¿No habló el camarero? Sí./¿Y al duque no conocí?/Él bajó por la escalera. /iQué venganza apercibo!)

${ }^{86}$ QUIJOTE I, 34: «Lotario creyó que Camila de la misma manera que había sido fácil y ligera con él, lo era para otro; que la mujer mala pierde el crédito de su honra con el mismo a quien se entregó, que cree que con mayor facilidad se entrega a otros.»

${ }^{87}$ GUILLÉN DE CASTRO, loc. cit. acto III: (Lotario y Camila)

-Señora,/porque rabiando no muera, mátame con este acero.

- ¿Qué dices? Mi bien.

- Camila, unos visibles engaños me dieron mortales celos./ Cegueme, y supo Anselmo tu amor./Y escondido/espera ver lo que yo le aseguré.

-Remediaré tus locuras/ y mis desdichas también.

(Vanse y sale Anselmo) 


\section{III.5.D. Farsa representada ante Anselmo escondido}

1. Camila al tanto de todo, para deshacer el entuerto de Lotario, idea un montaje de farsa con la comparsa de Leonela, engañando así al marido que se ha ocultado para ser testigo de la infidelidad de su esposa $^{88}$. Es el teatro dentro del teatro, el engaño a los ojos de aquel crédulo espectador ${ }^{89}$.

\section{2. (Lotario, Camila y Leonela)}

-En pasando de esta rayal tengo de pasarte el pecho...

(Hace la raya con la daga en el suelo)

- ¿Qué te ha podido ofender?

-Lotario, escúchame desde ahí:/ Lotario ¿Dite ocasión?/ ¿Tus antojos no hallaron desengaños en mi boca?/ Éstos serán mis abrazos. (Camila le ataca con la daga)

-Tente.

- Pues para matarte a ti/ mi valor faltado ha,/mayor hazaña serálmatarme por ello a mí.

(Sale Anselmo)

_iMi bien! (Anselmo: Ella se matara/si no llegara tan presto.)

\section{III.5.E. Leonela abofeteada se venga descubriendo el engaño}

1. Leonela cómplice de Camila, abusa de la situación de debilidad de su ama. Al saber Camila sus aventuras nocturnas y que el hombre de la escala era Culebro, enfurecida le da una bofetada. Esta reacción poco avisada con Leonela que al fin y al cabo es su cómplice, pone en marcha el desenlace final ${ }^{90}$.

-A ver mi afrenta y mi daño/¿dónde me podré esconder?/De una de estas colgaduras cubierto. (se esconde)

${ }^{88}$ I. ARELLANO, loc. cit. p. 75: Hay diálogo, monólogo, gesticulaciones histriónicas, puesta en escena con un puñal; en suma, recursos dramáticos construidos por el discurso y el gesto de la Camila actriz para Anselmo.

${ }^{89}$ GUILLEN DE CASTRO, loc. cit. acto III: (Camila y Leonela)

-Llama a Lotario. ¿Qué ha visto Lotario en mi,/aunque me adoró tres años?/¿qué nueva ocasión le di?/¿No sabe el ser y el valor /de mi esposo, a quien adoro?

-Corre, llama a ese traidor./ Hoy mi esposo y mi enemigo/ con este acero han de ver,/escrito en sangre, qué es ser/fiel esposa y falso amigo./

${ }^{90}$ I. ARELLANO, loc. cit. p. 86: Y hasta en su pelea con Leonela, confidente y ayudante de su traición conyugal, se acoge absurdamente a su honor (ya perdido). 


\section{2.-(Camila y Leonela)}

- ¿Has visto, Leonela,/en qué me he visto por ti?/Villana, ¿a tu infame amigo/por mi aposento has de entrar?

- ¿Tan buen ejemplo me has dado/que tanta culpa me das?/ ¿Tú ofendiendo a tu marido/ y en quien mio lo ha de ser/tan grande la ofensa ha sido?

\section{(Dale Camila un bofetón)}

-Quien de sus criadas fía,/de señora se hace esclava.

-Tú verás, pues soy mujer,/si mi agravio sé vengar.

(Queda Leonela y entra Anselmo)

— ¿Qué tienes, qué voces das?

-La verdad decirte quiero:/Que fue fingido/ cuanto viste en tu aposento.

\section{III.5.F. Desenlace con desafío}

1. El marido desafía al amante en duelo y muere en la pelea, desenlace que es modificación importante de Castro para el que la muerte de Anselmo no puede ser de melancolía y tristeza ${ }^{91}$.

2. (Cáese Anselmo y salen el Duque, la Duquesa)

-Matadle.

-No, Duque mío, oíd primero: Era Lotario mi amigo, ly celoso impertinente, len la ocasión que les di/ despeñáronse./ Quiero que de mi muertelalcance el perdón Lotario,/para que después hereden/ él y Camila, casados mis bienes./ Yo muero. Camila, Lotario... adiós.

-iOh amigo quién no te hubiera ofendido/Mas la culpa tú la tienes.

3. En la Novela la muerte de los tres protagonistas se sigue sucesivamente en poco tiempo. En la Comedia sólo muere Anselmo, prin-

${ }^{91}$ GUILLÉN DE CASTRO, loc. cit. acto III: (Hay ruido dentro de espadas y hablan Anselmo, Lotario y Camila)

—iLotario, amigo alevoso!/iY tú, adúltera insolente!

-iAnselmo, tente!

(Sale Camila sin chapines y descompuesta cabello y ropa)

(Salen Anselmo y Lotario)

-Lotario, muerto me has,/pero muerto he de matarte./ Alcanzarte quisiera / Mas...yo la culpa he tenido. 
cipal causa de los males, que recibe la muerte consciente de sus faltas, perdonando y rogando a los amantes que se casen.

\section{III.5.G. Final con bodas}

1. La terminación de la Comedia, tal como Castro la ha imbricado, no sería posible sin el Duque, esto es sin una autoridad capaz de sancionar las últimas voluntades de Anselmo, que deja heredero de sus bienes y su mujer a Lotario.

-Y yo quiero, que se cumpla/ lo que ordenó Anselmo./Dale a Camila la mano, Lotario.

-Pues ya remedio no tiene, /yo la doy.

-Y yo la tomo.

El final en boda corriente en la comedia nueva, une a Camila y Lotario que también morían en la Novela ${ }^{92}$.

2. Entendemos que no representa el triunfo del adulterio, sobre el matrimonio como apuntaba Américo Castro, porque el matrimonio pone fin y regulariza la unión adúltera ${ }^{93}$. Aunque tópico de terminación feliz ciertamente, es un desenlace original, que pone de manifiesto la independencia de Guillén de Castro frente al criterio usual del honor ${ }^{94}$.

3. Esta boda ha de ir acompañada de la de su doble, para que termine claramente en Comedia.

-Y tú Culebro y yo, ¿nos casamos?

-Aunque a todo el mundo pese.

$Y$ aquí la comedia acaba/del Curioso impertinente.

${ }^{92}$ Y. PALLÍN, Fabricadores, loc. cit. p. 14: «Pensemos por ejemplo en la aparente justicia dramática que nos ofrece el final feliz: ¿Anselmo muere reconociendo su culpa o bien ejecuta un último acto de manipulación decidiendo por Camila y Lotario un tal vez ya no tan deseado, matrimonio feliz?»

93 AMÉRICO CASTRO, El pensamiento de Cervantes, Barcelona/Madrid, 1972: Para Américo Castro, el triunfo de los adúlteros va contra los principios del honor del drama, y obedece a la adopción del punto de vista cervantino, opinión esta tanto más extraña cuando Cervantes precisamente mata a todos los protagonistas.

${ }^{94}$ ESMERALDA GIJÓN, Concepto del honor y de la mujer en Tirso de Molina, en Estudios, 1949, p. 487: Es la misma opinión que expresaba Valbuena Prat en su Historia de la literatura española. WEIGER, Sobre la originalidad e independencia de Guillen de Castro, en «Hispanófila», 3, 1967, pp. 1: Indica que es el único final posible dentro de la convención lopesca, y barroca. 


\section{EL DERECHO MATRIMONIAL APLICABLE}

La principal consideración jurídico matrimonial a que da pié la Comedia tiene su lugar preeminente precisamente cuando termina la Comedia.

Nos detenemos en la configuración del impedimento de crimen tal como se halla en el Liber Extra del Corpus Iuris Canonici, que es la legislación matrimonial que se aplica en el tiempo al que se refiere la Comedia de Guillén de Castro.

\section{IV.1. El impedimento de adulterio y crimen}

Ha sido siempre una cuestión delicada si el matrimonio debía ser permitido a los adúlteros, una vez que quedaban libres del anterior matrimonio.

\section{IV.1.A. Casarse con quien se adulteró}

1. Las legislaciones bárbaras soslayaban este problema pronunciando la pena de muerte contra la mujer adúltera y no teniendo en consideración el adulterio del marido.

Entre los pueblos civilizados que castigaban generalmente este delito con penas más suaves, no era fácil la solución, pues permitiendo semejantes matrimonios se facilitaba la rehabilitación de los adúlteros y se quitaba a los esposos la tentación de hacerse libres mediante el conyugicidio ${ }^{95}$.

2. La prohibición del matrimonio con la adúltera es recogida en las Leyes augusteas "Iulia et Papia», iniciándose una evolución que llega a Justiniano. En la Iglesia de los primeros siglos el adulterio era castigado con Penitencia pública como lo vemos en el Concilio de El$\operatorname{vira}(313)$ y en el de Ancira(314) ${ }^{96}$.

95 O. ROBLEDA, El matrimonio en Derecho Romano, Roma 1970 p. 197: Augusto habría adoptado una solución original para el caso de adulterio: Estaba prohibido casarse con la mujer adúltera; pero esta prohibición era general y no restringida al cómplice, mas para que esa prohibición operase, era necesario que la mujer hubiese sido condenada por adulterio.

96 TEJADA, Colección de Cánones y de Concilios de la Iglesia Española. Madrid 1849, vol. II, p. 25 Concilio de Elvira canon 69: Si algún hombre casado cometiere alguna vez adulterio, hará penitencia por cinco años y después será reconciliado. Obsérvese igual disposición en el caso de las mujeres. Y vol I, p. 40, Concilio de Ancira, canon 20: 
Una decretal del Papa León Magno (440-461)recoge un principio que será repetido constantemente: Nadie se case con la que antes adulteróo ${ }^{97}$.

Justiniano en el año 556 dando un paso cualificador circunscribe esta prohibición al matrimonio entre la adúltera y el cómplice declarándolo nulo ${ }^{98}$; disposición que fue canonizada en la Iglesia Oriental, pero que no se recibió entonces en la Iglesia Latina ${ }^{99}$.

3. La figura del adulterio con promesa de matrimonio, la encontramos en el Concilio Triburense del año 895, por primera vez como impedimento matrimonial según las Colecciones lo recogen ${ }^{100}$. Sin embargo, no se puede deducir que entonces el adulterio aun cualificado, fuese impedimento del matrimonio distinto del impedimento de $«$ Penitencia» ${ }^{101}$. Ni tampoco que fuese dirimente de las nupcias.

\section{IV.1.B. El conyugicidio y adulterio}

1. Este impedimento se producía también por haber dado muerte al otro cónyuge con la intención de casarse ${ }^{102}$.

Si alguno cometió adulterio, le es necesario para conseguir la purificación hacer siete años de penitencia.

${ }^{97}$ GRACIANO, Decretum, Cau. XXXI, q. 1, c. 1: Esta norma antigua parece haber sido una simple aplicación del principio más general, según el cual nadie debía casarse con una mujer mancillada por adulterio o por fornicación.

98 JUSTINIANO, Novelas, 134, c. 12: Así lo establece en esta Novela, donde la prohibición general que existía, se limita a sólo la adúltera y su cómplice.

${ }^{99}$ S. AGUSTÍN, De nuptiis et concupiscentia, lbr. I, cap. 10, en MIGNE Patrologia Latina vol. 44, col. 420: Finalmente muerto el varón con el que hubo verdadero matrimonio, puede tenerse también verdadero matrimonio con el que antes adulteró.

100 MANSI, Sacrorum conciliorum nova et amplissima collectio, Florencia 1759, vol. XVIII, col. 152, Concilio Triburense can. 40: Uno estupró a la esposa de otro y además de tal delito le dio juramento viviendo su marido, que después de la muerte de su legítima consorte la tomaría como esposa, cosa que hizo. Tal matrimonio lo prohibimos y lo anatematizamos. Lo recogen IVO DE CHARTRES, Panormia, VII, c. 9, M. L. vol. 161, col. 1281; BURCHARDO, IX, c. 66, M. L. vol. 140, col. 826

101 WERNZ VIDAL, Ius Canonicum, vol. V, Roma 1946, p. 411: Durante la Penitencia pública se prohibía la celebración del matrimonio y la comunicación sexual entre los esposos. Una vez transcurrido el tiempo de la Penitencia y muerto el cónyuge nada se oponía ya al matrimonio de los adúlteros. Por tanto el adulterio como tal no producía impedimento, sino de una manera mediata en razón de la Penitencia pública.

${ }^{102}$ IVO DE CHARTRES, Epistola 170, M. L. vol. 162, col. 173: Sobre tu feligrés que dio muerte al marido de una mujer y después la tomó por esposa, respondemos que si la mujer puede descargar su conciencia de la muerte del marido, y si el varón como decís, puede probar legítimamente que viviendo dicho marido no adulteró con aquella mujer y que tampoco dio muerte a aquel hombre con la esperanza de casarse, puede concedérsele casarse con quien quieran en Cristo. 
En el Concilio de Verberie (768-772) se nos ofrece una aproximación al impedimento de conyugicidio ${ }^{103}$. Pero esta norma que figura en varias Colecciones, no la recogió Graciano en su Decreto ${ }^{104}$.

2. El Concilio de Worms del 829, nos presenta el caso del conyugicida sin más, al que se prohibía ulterior matrimonio mientras se le sometía a Penitencia pública ${ }^{105}$. Lo aportarán Graciano y Lombar$\mathrm{do}^{106}$.

En el Concilio Meldense del año 845 aparece por primera vez la figura de adulterio con conyugicidio estableciendo que no podía contraer con su cómplice después de la muerte del otro ${ }^{107}$.

\section{IV.1.C. El Decreto de Graciano y los Decretistas}

1. Para Graciano el adulterio sin más prohíbe el matrimonio, antes de haber realizado la penitencia; pero sólo el adulterio cualificado será el impedimento dirimente que la doctrina designa con la expresión de «crimen»: a saber cuando uno de los adúlteros causa la muerte del cónyuge para hacerse libre, y en el caso del adulterio con promesa de matrimonio ${ }^{108}$.

${ }^{103}$ MONUMENTA GERMANIAE HISTORICA, Capitularia, vol. II-I, p. 40. Concilio de Verberie, canon 5: Si alguna mujer se pusiese de acuerdo con otros hombres en la muerte del marido, y el referido marido defendiéndose diese muerte a alguno de ellos, el susodicho marido puede abandonar a tal esposa y si lo desea casarse con otra. Pero en cambio a ella se le someterá a penitencia sin esperanza de matrimonio. En el LIBER EXTRA (IV, tit. 19, cap. 1 «Si qua mulier»), Raimundo de Peñafort lo enmendará advirtiendo que el nuevo matrimonio del cónyuge inocente ha de ser «después de la muerte de la esposa».

${ }^{104}$ GRACIANO, Cau. XXXI, q. I, c. 6 Figura como «palea» que fue posteriormente añadida, no siendo conocida por Rolando.

${ }^{105}$ M.G.H. vol. I, p. 353, Concilio Wormatiense: Quien diese muerte a su esposa sin ley y sin causa y tomase otra haga pública penitencia, y si se mantuviese contumaz, sea anatematizado hasta que dé su asentimiento. El texto alcanza su total comprensión si se tiene en cuenta que termina diciendo: La misma norma se aplicará a quien diese muerte a su señor.

106 GRACIANO, Cau. XXXIII, q. 2, c. 7, y LOMBARDO, I, 71.

107 M.G.H. vol. III, p. 117: Concilio Meldense canon 69: Si alguno, viviendo el marido es acusado de adulterio con la cónyuge de aquél, y más adelante muerto éste, se tiene conocimiento de que la ha tomando por esposa, sea sometido a penitencia pública. Si fuere conveniente el obispo después de la penitencia puede concederle el matrimonio, a no ser que se tenga noticia que él o la mujer mataron al que había muerto.

${ }_{108}$ GRACIANO, Cau. XXXI, q. 1, dictum post c. 3: El que nadie se case con la que antes adulteró, se ha de entender, si es que no hubiese realizado ya la correspondiente penitencia y si no hubiese maquinado en la muerte del marido, o si viviendo éste no le dio fe de que la tomaría por esposa si sobrevivía a su marido. 
Bernardo de Pavía, a finales del siglo XII nos consigna la referencia histórica ${ }^{109}$. Y Tancredo (1212-1214) enumera y distingue ya tres especies de impedimento de crimen: adulterio con promesa de matrimonio, adulterio con la atentación de matrimonio, y adulterio con conyugicidio.

La Glosa al Decreto puntualiza sobre las figuras del impedimento de crimen ${ }^{110}$. Y matiza oportunamente datos que se han de tener presentes $^{111}$.

\section{IV.1.D. En las Decretales y los Decretalistas}

1. En el «Liber Extra» de las Decretales fueron incluidas las normas de los Papas Alejandro III ${ }^{112}$, Inocencio III ${ }^{113}$ y Celestino III ${ }^{114}$, quedando fijado el impedimento de crimen en sus figuras de adulterio, conyugicidio y cooperación en el mismo.

${ }^{109}$ BERNARDO DE PAVÍA, Summa Decretalium Lib. IV, tit. 7: «Existió en tiempos pasados la prohibición general de que nadie tomase por esposa a aquella a la que antes había mancillado en adulterio; pero posteriormente la prudencia redujo esta prohibición a dos casos, a saber si el adúltero había maquinado la muerte del primer marido y también cuando le había dado juramento de tomarla por esposa al morir el primero».

${ }^{110}$ GLOSA AL DECRETO, Cau. XXXI, q. 1, v. "adulterio»: Puede hacerlo excepto en tres casos: si viviendo el marido le hubiese dado fe de que se casaría con ella si aquél moría antes; si uno de ellos había maquinado en la muerte del mismo siguiéndose el efecto; y en tercer lugar cuando se hubiese casado públicamente con la misma.

111 GLOSA AL DECRETO, ibidem, q. 4, v. «occidise»: Le ha de dar muerte precisamente para casarse; otra cosa es si ocurre por casualidad o porque son enemigos o por otra causa...Y si la maquinación no hubiese surtido efecto, no se produce el impedimento, como si hubiese pensado envenenarle y no le dio suficiente veneno; y tampoco lo impide a quien ratifica la muerte pero no la ordenó.

112 LIBER EXTRA IV, tit. VII, c. 3 Alejandro III «Super hoc quod quaesivisti»: Sobre lo que preguntaste si le está permitido a alguno contraer matrimonio con la mujer con la que viviendo su esposa se unió de hecho, respondemos a tu solicitud que si la adultera intervino de algún modo en la maquinación de la muerte de la esposa, le diese el adúltero promesa o no de que una vez que aquella muriese la tomaría en matrimonio, según los cánones le está prohibido perpetuamente el matrimonio con ella.

${ }^{113}$ LIBER EXTRA IV, tit. VII, c. 6, Inocencio III «Significasti nobis»: Respondemos a tu pregunta que a no ser que uno de ellos hubiese maquinado en la muerte de la anterior cónyuge difunta, o viviendo ésta le hubiese dado fe de que contraería matrimonio, tengas por legitimo el matrimonio de que se trata.

${ }^{114}$ LIBER EXTRA III, tit. XXXIII, c. 1, Celestino III «Laudabilem»: Unos sarracenos que estaban cautivos de los cristianos, dieron muerte a los maridos cristianos de algunas mujeres con insidias y maquinación de las mismas. Luego dichos sarracenos por la persuasión de aquellas mujeres se convirtieron a la fe cristiana. Se consulta si según Derecho las podrán tomar por esposas, y si el matrimonio será válido. Se responde que esta cuestión fue resuelta por el Concilio Triburense (Meldense), según el cual si hubiesen maquinado maliciosamente la muerte de aquellos, no pueden casarse con los mismos. 
En la primera figura, una decretal de Gregorio IX especifica que además del adulterio se requiere la promesa del matrimonio ${ }^{115}$; Raimundo de Peñafort completa las precisiones de la Decretal ${ }^{116}$.

2. En cuanto a las figuras de homicidio, además del adulterio se requiere en todas ellas la actuación criminal con muerte seguida por la misma, según la Glosa ${ }^{117}$, y según lo explica el Panormitano ${ }^{118}$. Asimismo se requiere la intencionalidad de contraer ${ }^{119}$.

Ahora bien si se le dio muerte por otra causa (por casualidad, en combate, por odio), y no para poder casarse, no será impedimento según el Hostiense ${ }^{120}$, Sánchez ${ }^{121}$ y otros autores ${ }^{122}$.

3. Es en la Decretal «Laudabilem» de Celestino III donde aparece por primera vez a nivel universal el último supuesto de este impedimento en la figura del llamado crimen «utroque machinante», es decir

${ }^{115}$ LIBER EXTRA IV, tit. VII, c. 8, Gregorio IX, «Si quis uxore»: Si alguno viviendo su esposa prometiese con juramento a alguna que contraería con ella o de hecho contrajo, si no tuvo trato sexual con ella ni antes ni después en vida de su legítima esposa, aun cuando a ambos haya que imponerles una penitencia porque delinquieron con ello, no se ha de dirimir tal matrimonio. En cambio no se deberá tolerar si en vida de aquella, antes o después de la promesa se hubiese mancillado con adulterio.

${ }^{116}$ RAIMUNDO DE PEÑAFORT, Summa de Matrimonio, Roma 1978, IV. tit. IX, 2, col. 950: «Advierte que es necesario que la persona que ha dado o recibido la promesa de matrimonio, sepa que se compromete con una persona casada; si ésta de buena fe creía a la otra libre de todo vínculo, no se da el impedimento».

${ }_{117}$ GLOSA A EXTRA, IV, tit. VII, c. 3, v. «machinata»: Entiéndese con su efecto. Algunos dicen que es bastante la tentativa sin efecto, lo cual no es verdad. Y si alguien da muerte a otro en la guerra y no con el propósito de casarse con su esposa, ¿podrá tomarla por esposa? Hay que decir que sí.

118 NICOLÁS DE TUDESCHI, ABAD PANORMITANO, Commentarium in IV et $V$ Decretalium Librum, Venecia 1578, IV, tit. VII, c. 3, n. 4: «Esta decretal presupone que la esposa de aquel ha muerto realmente, y así lo entiende Juan Andrés para el que la maquinación sola sin que se haya seguido su efecto no impide el matrimonio con la adúltera, cosa que a mi me convence más, porque tratándose de un impedimento de derecho positivo no se debe restringir la facultad de contraer matrimonio en contra del derecho divino».

${ }^{119}$ Cuando sólo una de las partes ha causado la muerte, se requiere la intención en quien comete el crimen de servirse del mismo para poder contraer, sin que sea necesario que la parte que no lo comete sea conocedora de la autoría.

${ }^{120}$ HOSTIENSIS, Summa Aurea, Venecia 1581, col. 1320: «Si alguno diese muerte fortuitamente al marido de una mujer no se impide el matrimonio con ella».

${ }^{121}$ TOMÁS SÁNCHEZ, De sancto Matrimonii Sacramento, vol. II, Venecia 1726, Disp. 78, 13. Cita una larga lista de autores encabezados por Sto. Tomás (In IV, d. 37, 2. 2 , art. 2

${ }^{122}$ F. SCHMALZGRUEBER, Jus Ecclesiasticum, vol. IV, prs. 1. ${ }^{\circ}$, Roma 1844, p. 530, n. 52: «Si el homicidio se causa con otra intención que no sea el contraer matrimonio con el adúltero, no se contrae el impedimento; v.g. para poder realizar más libremente su lujuria.» 
con cooperación de los dos futuros contrayentes, en cuya figura no se requiere que se haya dado adulterio entre los maquinantes según lo entienden Inocencio IV y el Hostiense con otros autores ${ }^{123}$.

Después de Celestino III no se dictaron nuevas normas sobre este impedimento, de suerte que la disciplina del mismo continuó ya fijada y vigente con todas sus figuras en la Codificación de 1917, hasta la reforma del Código canónico de 1983 en que experimentó una importante reducción.

3. En nuestro Derecho Histórico, las Partidas dedican una ley al adulterio en la que se exponen puntualmente los casos en que se prohíbe el matrimonio ${ }^{124}$.

\section{IV.2. Indiscrecion de juicio e incapacidad conyugal}

\section{IV.2.A. En la Novela cervantina}

1. Hay que destacar que Cervantes con ejemplaridad de esta novela corta, se sitúa en un caso matrimonial posiblemente no apreciado como nulidad por los canonistas de su tiempo, para los que ni el alcance de la «suficiente» discreción de juicio ni la incapacidad por motivos de naturaleza psíquica eran suficientemente ponderables, como no fuese en los llamados entonces casos de amencia y demencia, clasificación que ella misma nos muestra una visión escasamente científica de los problemas del consentimiento.

Parece como si Cervantes en su reflexión sobre la doctrina del matrimonio, vislumbrarse algo a lo que se llegará después del desarrollo

123 TOMÁS SÁNCHEZ, loc. cit. 78, 23 «Es bastante para incurrir en el impedimento de crimen por maquinación si mandó o aconsejó la muerte; pero si sólo aprobó, hay que decir que no intervino en la muerte ya que la ratificación no produjo la muerte».

${ }^{124}$ ALFONSO X, Partidas IV, tit. II, 1. 19: Si acaesciese que se muera el marido de aquella que fizo el adulterio, bien podria despues casar con ella aquel con quien lo fizo no habiendo otra mujer, fueras ende de tres razones. La primera, si cualquier dellos matase o fiziese matar o fuese en consejo de la muerte del otro marido o de la muger con entención de que se casasen después en uno. La segunda si aquel que yace con ella le jurase y le prometiese que casaría con ella despues que fuese muerto su marido. La tercera si alguno yoguiese con muger agena e se casase con ella bivo, ca maguer se muriese el marido della, no valdria el casamiento que antes oviese fecho. Eso mismo seria de la muger que fiziese adulterio con ome casado en alguna de las maneras desuso dichas...Los que se casasen en alguna de las maneras desuso dichas, develos la Eglesia departir, fuera ende si alguno dellos non sopiese que era casado el otro cuando se caso con el. Ca entonces en escogencia es de aquel que non lo sabe, de fincar con el otro o departirse del e casar a otra parte. 
adecuado del contenido intelectivo-volitivo del consentimiento y de la relación matrimonial interpersonal a la luz de la Psicología y la Antropología.

2. Es cosa expresada ahora en el nuevo Código Canónico en el canon 1095, que la entrega y aceptación mutua en que consiste el consentimiento matrimonial según el can. 1057, debe tener cabida tanto en la valoración previa del entendimiento como en las posibilidades de la voluntad de las personas que lo contraen. El contraerlo sin esa valoración y capacidad hace nulo el matrimonio.

\section{IV.2.B. En la Comedia de Guillén de Castro}

Muchos de los críticos que han comparado los dos Curiosos han venido a decir que Guillén hace un esfuerzo por dar lógica y explicar las motivaciones de 1 os personajes con que sus actos tienen sentido, haciendo que los acontecimientos ocurran mediante un sistema constatable de causa y efecto.

Guillén de Castro para obviar la inverosimilitud, explicita el tema de los celos. Para ello introduce el Acto primero con la relación amorosa previa de Lotario y Camila, totalmente ausente de la Novela. Con ello se habría reducido la posibilidad de un matrimonio nulo ciertamente por falta de discreción de juicio y aun por incapacidad conyugal, conduciéndolo a una situación de celos, que al parecer podrían no ser irracionales e infundados. No sería el caso de unos celos delirantes, que buscan con avidez todas las pruebas de su presunto infortunio ${ }^{125}$.

\section{IV.3. La imposicion de un matrimonio}

Hay otro capítulo matrimonial no aplicable a la Novela, propio de la Comedia: La imposición del matrimonio a la protagonista y no precisamente el querido por la misma, sino el apañado por la avaricia de su padre, y propuesto por su enamorado que se cree equivocadamente obligado a hacer esta cesión por reconocimiento a su amigo y bienhechor.

El Concilio de Trento se había pronunciado anatematizando la costumbre de imponer los señores los matrimonios a sus sometidos y

${ }^{125}$ NORBERT SILLAMY, en Diccionario de Psicología: Los celos en una consideración general como «estado afectivo caracterizado por el miedo de verse desposeído de lo que se tiene, como el amor de una persona. En un sentido más estricto se entiende por celos «el sentimiento producido por el temor de que la persona amada prefiera a otros». 
condenó asimismo la necesidad del consentimiento paterno para la validez del matrimonio de los hijos de familia, defendiendo la libertad de los mismos ${ }^{126}$. La necesaria aprobación de sus Señores del matrimonio de los nobles era costumbre que venía del Derecho germánico.

No estaríamos en el caso ante una nulidad matrimonial por este capítulo, porque la esposa aunque quejosa en su interior acepta el matrimonio que se le propone.

\section{APLICACION DEL DERECHO MATRIMONIAL A LOS HECHOS}

\section{V.1. Falta de discrecion de juicio y capacidad conyugal}

\section{V.1.A. La cuestión en la Novela}

1. Subrayamos que en El Quijote es el Cura el que lee en voz alta la Novela a lo que asisten los enamorados como alumnos que escuchan la lección o catequesis de la doctrina católica sobre el matrimonio $^{127}$.

Amezua tiene dicho que la larga exposición que hace Lotario a su desdichado amigo Anselmo sobre lo que es el matrimonio cristiano, es más propia de un Tratado de Teología moral, que de una novela» ${ }^{128}$.

Parece como si las explicaciones de Cervantes sobre la institución del matrimonio y sobre la virtud del matrimonio para hacer de los contrayentes una unidad espiritual las hubiese tomado del Decreto del Tridentino sobre el matrimonio, traduciéndolas al lenguaje vul$\operatorname{gar}^{129}$.

${ }^{126}$ CONCILIO TRIDENTINO, en Ses. XXIV, cap. IX

${ }^{127}$ KENNETH BROWS, El Curioso impertinente, una homilía novelesca, en «Cervantes, su obra y su mundo», Madrid 1981, p. 794. El Cura cumple un papel de suma importancia; "El curioso impertinente» es un sermón pertinente en aquella ocasión, aunque el Cura predicador no lo alcance del todo, cuando crítica la novela diciendo que algo tiene de imposible.

${ }^{128}$ AGUSTIN G. DE AMEZUA Y MAYO, Cervantes creador de la novela corta española, Madrid, 1982.

${ }^{129}$ PAUL DESCOUZIS, ha podido hacer el estudio comparativo de estos textos poniéndolos en columnas paralelas, concluyendo, «al echar una mirada retrospectiva resulta poco menos que imposible negar al texto cervantino el valor histórico de catequesis a favor de la ideología postridentina del matrimonio». Este texto clave en el efecto del matrimonio que hace de los cónyuges una unidad en la que se comple- 
2. En el caso que estudiamos, parece que la falta de discreción de juicio habría que referirla a un anomalía afectiva de Anselmo, que le impediría una valoración adecuada del contenido esencial de la verdadera entrega conyugal mutua. Asimismo aparece la incapacidad del esposo para asumir las obligaciones esenciales del matrimonio por causas de naturaleza psíquica, que se concreta en una relación interpersonal verdaderamente conyugal.

Estos capítulos que se intuyen tendría una prueba fundamentalmente técnica, siendo imprescindible para apreciarlo el estudio psicológico y aun psiquiátrico de la persona del esposo.

\section{V.1.B. Celos e infelicidad en la Comedia}

1. Podría interpretarse como un caso de celos como parece lo más probable, celos que no serían demenciales por infundados. La aberración de Anselmo consistiría en querer probar la fidelidad de Camila por medio del mejor amigo a quien obliga a seducirla, que no es necesariamente la locura de la Novela.

2. En el caso de Anselmo se ha llegado a interpretar de una homosexualidad inconsciente que no la asume el sujeto, en cuyo caso la sospecha respecto a Camila correspondería al síntoma de su propia pulsión reprimida. Se ha dicho que los celos no son sino síntomas de infidelidades propias, latentes y reprimidas. Así su defecto lo justificaría con la representación de una Camila posiblemente infiel.

Pero parece más cierto que para Guillén sería un caso de infelicidad en el matrimonio, tema importante que aborda con frecuencia, y no precisamente de nulidad matrimonial.

\section{V.2. Sobre el impedimento de adulterio y crimen}

Aparentemente el capítulo más ajustado es el referido al impedimento de crimen: adulterio y homicidio que podrían constituirlo si se diesen las condiciones que se requieren.

mentan y funden espiritualmente, está inspirado directamente en el Decreto sobre el Matrimonio de la Sesión XXIV del Concilio de Trento habida el 11 de noviembre de 1563. 


\section{V.2.A. Adulterio con promesa de matrimonio}

Parece que el adulterio es cierto, pero lo que no se constata es que se haya dado expresa promesa de matrimonio. Parece como si Guillén hubiese evitado con cuidado para no incurrir en este impedimento, el introducir referencia alguna de matrimonio entre los adúlteros; por más que aquella situación lujuriosa se prolongue, no parece que haya querido ser el modo de asegurar una futura unión conyugal.

\section{V.2.B. En cuanto al homicidio}

La cuestión de más interés la representa el homicidio por parte del adúltero, que no se realiza con intención de liberarse del obstáculo que representaría para la nueva boda; sin duda, acaece en defensa propia, pues es el esposo burlado el que ha querido vengar su ofensa.

Por ello en el caso no parece que se haya incurrido en el impedimento de crimen. Diríamos que Guillén ha extremado la aproximación a este impedimento, pero ha tenido buen cuidado de que no se caiga en él. ¿Es pura casualidad o acabado conocimiento del Derecho?

\section{CONCLUSIONES}

1. La recreación de Guillén de Castro se ve sometida a la necesaria comparación con el «original» del que parte, que frecuentemente ha ofrecido un saldo a favor de la Novela, pues apostando por Cervantes novelista se juega sobre seguro.

2. Ello no quita para que el autor haya dotado a su Comedia de un toque que lo distingue, haciendo de ella una de las cimas de su dramaturgia. En las divergencias introducidas es donde se produce la verdadera creación: en ellas aparece su voz personal, pues aunque sea herencia del pasado es a la vez afirmación de una mentalidad nueva.

3. Guillén a diferencia de Cervantes y tal vez por la diferencia del género literario de que se sirve, más que a cuestiones de principios atiende en el caso a situaciones prácticas. Cervantes se ofrece en el caso más teólogo exponiendo los principios que hacen de los casados «una sola carne»; Guillén diríamos que más jurista, encuentra en el fracaso de un matrimonio una solución para una pareja. 
4. Apuntamos y dejamos abierta la consideración de Guillén de Castro desde un ángulo jurídico matrimonial, porque en lo poco que hemos estudiado de sus obras advertimos que a diferencia de sus contemporáneos se muestra preocupado por los problemas conyugales. Por otra parte no deja de ser sugestivo el que en el caso que analizamos, sepa muy bien donde están los límites del derecho para no sobrepasarlos en una solución coherente del problema. 